\title{
O estudo experimental sobre o magnetismo na Idade Média, com uma tradução da carta sobre o magneto de Petrus Peregrinus
}

\author{
Experimental researches on magnetism in the Middle Ages, with a translation of Petrus Peregrinus' \\ letter on the magnet
}

\author{
Roberto de Andrade Martins*1,2 \\ ${ }^{1}$ Instituto de Física de São Carlos, Universidade de São Paulo, São Carlos, SP, Brasil \\ ${ }^{2}$ Fundação Municipal de Ensino Superior de Bragança Paulista, Bragança Paulista, SP, Brasil
}

Recebido em 15 de Agosto, 2016. Aceito em 04 de Setembro, 2016.

\begin{abstract}
Este artigo expõe o desenvolvimento sobre o conhecimento medieval a respeito do magnetismo, dando especial ênfase aos estudos de Petrus Peregrinus (Pierre de Maricourt). Este autor muito importante, mas pouco conhecido, escreveu a obra mais antiga que conhecemos (1269) onde aparecem os conceitos de polos magnéticos e as leis qualitativas de atração e repulsão entre eles. A parte final deste artigo contém uma tradução completa, feita a partir do texto latino, da "Epistola de magnete" desse autor, através da qual é possível perceber que Petrus Peregrinus realizou um estudo experimental sobre o magnetismo. O estudo de sua contribuição pode ajudar a superar alguns equívocos e preconceitos existentes sobre a ciência medieval.
\end{abstract}

Palavras-chave: história da física, magnetismo, bússolas, polos magnéticos, Petrus Peregrinus

This paper presents the development of the medieval knowledge about magnetism, giving special attention to the studies of Petrus Peregrinus (Pierre de Maricourt). This very important but little known author wrote the oldest work known (1269) where the concept of magnetic poles and the qualitative laws of attraction and repulsion between them are described. The final part of this article contains a complete translation from Latin to Portuguese of the "Epistola de magnete" written by this author. By reading it one can realize that Petrus Peregrinus made an experimental investigation of magnetism. The study of his contribution may help to overcome some mistakes and the prejudices concerning medieval science. Keywords: history of physics, magnetism, magnetic compass, magnetic poles, Petrus Peregrinus

\section{Introdução}

Desde a Antiguidade os pensadores gregos já conheciam a existência dos ímãs naturais e sabiam que eles atraíam o ferro. Além desse fenômeno básico, descrito por Tales de Mileto, Platão, Aristóteles e outros autores antigos, pouco se sabia sobre o magnetismo, até o período medieval. Costuma-se considerar que a obra De magnete de William Gilbert (publicada em 1600) foi o primeiro estudo experimental importante sobre os fenômenos magnéticos. No entanto, alguns séculos antes, em 1269, um obscuro autor medieval

* Endereço de correspondência: roberto.andrade.martins@gmail.com chamado Petrus Peregrinus (em latim) ou Pierre de Maricourt (seu provável nome em francês) escreveu uma importante carta sobre os ímãs, na qual descreveu alguns cuidadosos experimentos e indicou propriedades que parecem não ter sido conhecidas antes, como a existência dos polos magnéticos e os fenômenos de atração pelos polos opostos e repulsão pelos de mesmo tipo. Ele descreveu também alguns tipos de dispositivos semelhantes a bússolas - mas outros autores europeus já haviam se referido ao fenômeno de orientação das bússolas, antes dele.

Este artigo apresenta primeiramente uma análise sobre o conhecimento medieval sobre magnetismo, incluindo as primeiras informações europeias a res- 
peito da bússola e a teoria islâmica de orientação magnética como um efeito produzido pelos astros (uma concepção que foi adotada por Petrus Peregrinus). Depois, situa esse autor medieval e sua obra. Por fim, apresentamos uma tradução completa da Epistola de magnete, acompanhada de comentários e esclarecimentos.

Acreditamos que a divulgação deste autor e desta pesquisa medieval é bastante importante, sob os pontos de vista educacional e cultural. Por um lado, ainda predomina uma visão inadequada de que a Idade Média teria sido uma "era das trevas", na qual apenas eram reproduzidos os ensinamentos antigos. Essa opinião está completamente equivocada. Há um grande número de pensadores medievais originais, tanto no mundo islâmico quanto na Europa, que deram importantes contribuições à mecânica, à óptica, à astronomia e ao magnetismo. Outro preconceito muito difundido é o de que não existia experimentação científica antes de Galileo. Tratase de outra opinião popular errônea. Não existe o "pai da ciência experimental". O processo de experimentação já estava presente desde a Antiguidade (por exemplo, nos estudos de Aristóteles sobre os seres vivos), tendo aumentado de importância no período medieval entre os pesquisadores islâmicos (como, por exemplo, Ibn Al-Haytham) e ressurgido na Europa desde o tempo de Roger Bacon (contemporâneo de Petrus Peregrinus). Esperamos que este artigo possa contribuir para uma melhor compreensão da ciência na Idade Média e para superar o preconceito existente a respeito desse período da história.

\section{A concepção astrológica sobre o magnetismo, entre os autores islâmicos}

Durante o período medieval, os autores de língua árabe desenvolveram uma interessante abordagem a respeito do magnetismo, associando-o à influência astrológica. Um importante astrólogo da Pérsia, Masha'allah ou Messahalla (aprox. 762-815) escreveu [1]:

A ação dos planetas sobre este mundo é semelhante à do magneto sobre o ferro; pois assim como o ferro é atraído por essa pedra até uma distância conhecida, da mesma forma toda criatura e todas as coisas que estão sobre a Terra são produzidas pelo movimento dos planetas $[\ldots]$.

Albumasar (século IX) desenvolveu a mesma ideia, acrescentando-lhe mais detalhes. Depois de descrever o poder dos ímãs de atrair o ferro à distância, mesmo através de outros corpos sólidos (como o bronze), ele afirmou [2]:

Portanto, é desse modo que os corpos celestes movem os corpos terrestres e os mudam e transformam, e os dissolvem. E assim ocorre por causa do poder que existe nos corpos celestes de mover e mudar e dissolver os corpos terrestres; e porque existe nos corpos terrestres a capacidade de receber o movimento, a mudança e a alteração a partir do movimento dos corpos superiores e por sua conexão natural.

Messahalla apontou uma conexão mais específica entre os poderes celestes e o magnetismo. Em uma obra da qual só se conhece a versão latina, De quindecim stellis, quindecim lapidibus, quindecim herbis et quindecim imaginibus, ele estabelece uma conexão entre quinze minerais e quinze estrelas brilhantes, afirmando em um trecho [3]:

\section{A décima-primeira pedra é chamada mag- neto; e sua cor é como a cor do ferro claro e bem polido. Sua virtude é a de atrair o ferro para si e de mostrar a parte do céu e o lugar onde gira Benenays, e ela mostra o polo do mundo [polum mundi] no lado setentrional [norte]. E com essa pedra os encantadores fazem muitas ma- ravilhas. Sua estrela é Benenays.}

Benenays (um nome árabe) indica uma das estrelas da Ursa Maior que era utilizada pelos navegantes para identificar a posição do polo norte celeste.

Esse texto extremamente importante, que tem sido ignorado pelos historiadores do magnetismo, indica que no século VIII os pensadores árabes $\rrbracket^{1}$ já

\footnotetext{
${ }^{1}$ É importante esclarecer uma questão de nomenclatura. A palavra "árabe" pode significar uma pessoa nascida na Arábia ou alguma coisa proveniente dessa região geográfica, mas costuma ser utilizada para indicar uma pessoa que pertencia à cultura associada ao Islamismo, iniciada na Arábia e transmitida geralmente através do idioma árabe, que se espalhou por grande parte do mundo, durante o período medieval.
} 
sabiam que os ímãs giram e apontam para o norte; e também mostra que se atribuía uma relação entre os astros e o magnetismo.

Um estudo recente de Nicolas Weill-Parot [4] mostrou que essas ideias tiveram forte influência no pensamento europeu, desde o século XII. Assim, não apenas a semelhança entre as influências astrológicas e o magnetismo, mas a ideia explícita de que uma estrela fixa exerce uma ação direta sobre os ímãs e faz com que eles apontem para o norte, são propostas encontradas entre os pensadores que escreveram em árabe, nos séculos VIII e IX.

Isso parece indicar que, desde essa época, os autores islâmicos já conheciam algum tipo de bússola, ou seja, um instrumento magnético que aponta na direção norte-sul. No entanto, só encontramos descrições mais diretas sobre o uso de agulhas magnéticas por parte de navegadores islâmicos em textos do século XIII [5]. É difícil compreender a grande lacuna encontrada desde Messahalla até esse período. Pode ser que o conhecimento da propriedade direcional dos ímãs tivesse sido um conhecimento erudito, por parte dos astrólogos e astrônomos, não tendo se transformado em uma técnica náutica usual até alguns séculos depois. Pode ser, no entanto, que o uso da bússola pelos navegantes islâmicos tenha se iniciado na época de Messahalla, mas que não tenha sido descrito nos textos árabes conhecidos simplesmente porque os escritores apenas se interessavam por discussões eruditas e não pelas técnicas utilizadas nos navios.

\section{O surgimento das bússolas na Europa}

As notícias mais antigas que conhecemos a respeito da bússola, por parte de autores europeus, surgiram no final do século XII e início do século XIII [6]. Há cerca de 20 escritos considerados autênticos e significativos sobre o assunto, posteriores a 1170 e anteriores a 1270 . Os três que são considerados mais antigos são de Alexandre Neckam (1157-1217), Guyot de Provins (que escreveu entre 1184 e 1210) e Jacques de Vitry (aprox. 1165-1240), provavelmente neste ordem [7]. O tema é muito discutido e diversos trabalhos apontam autores anteriores a esses; porém, as pesquisas históricas mais confiáveis que conhecemos rejeitaram essas alegações.

Alexandre Neckam nasceu na Inglaterra em 1157, fez seus estudos iniciais lá, passando depois um período em Paris, de onde retornou em 1185. Foi professor na universidade de Oxford e se tornou monge da ordem Agostiniana. Dois de seus trabalhos mencionam a bússola: uma obra sobre gramática chamada De nominibus utensilium, escrita em Paris, entre 1175 e 1183; e um tratado sobre filosofia natural, De naturis rerum, escrito entre 1197 e 1204. As duas passagens relavantes são estas [8]:

Entre os bens de um navio, deve haver uma agulha montada sobre uma ponta. A agulha roda e gira, até que a ponta da agulha aponta para o oriente [cuspis acus respiciat orientem]. E os navegantes saberão como dirigir seu curso quando Cynosura [Ursa Menor] está oculta pela perturbação da atmosfera [...]

Assim, quando os navegantes velejam sobre o mar, e quando no tempo nublado não podem se beneficiar da luz do Sol, ou quando o mundo está envolto por trevas, na sombra da noite, e eles ignoram para que direção do mundo o seu navio está se dirigindo, esses navegantes colocam a agulha sobre a pedra magnética [acum super magnetem ponunt], a qual gira em um círculo até que seu movimento cessa, e então sua ponta se volta diretamente para a região setentrional [norte].

Devemos enfatizar que em nenhuma dessas passagens Neckam afirma que a bússola seria uma novidade. Na primeira delas ele descreve uma agulha magnética suspensa sobre uma ponta, e sabe-se que esse tipo de dispositivo não é o mais antigo; originalmente, a agulha magnética era presa a um pequeno pedaço de madeira ou palha e colocada para flutuar na água (Mitchell, 1932, p. 125). Na primeira passagem, Neckam indica que a agulha aponta para leste, mas na segunda afirma, corretamente, que ela aponta para o norte.

Na obra De naturis rerum, Neckam apresenta algumas propriedades do magnetismo, afirmando que "o magneto atrai pela semelhança entre as partes e repele pela diferença entre as partes" (ou seja, exatamente o contrário do que ocorre) e também escreve que "o magneto atrai o ferro, mas não outro magneto, mesmo que tenha grande semelhança a ele; pois o magneto se opõe ao magneto, por oposição igual e mútua" [9]. Percebe-se que Alexander Neckam não tinha bons conhecimentos sobre a polaridade dos 
ímãs, nem sobre as leis de atração e repulsão dos mesmos.

O autor seguinte que conhecemos e que cita a bússola é um padre autor de obras poéticas, Guyot de Provins. Não são conhecidas as datas de seu nascimento e morte, mas sabe-se que ele produziu algumas de suas obras entre 1184 e 1210. Sua obra mais famosa foi uma Bíblia satírica, escrita talvez entre 1204 e 1209 [10], onde se encontra uma passagem sobre a bússola, que é utilizada de forma alegórica. Guyot criticou o papa, por ser muito mutável, e sugeriu que ele deveria ser como a estrela polar, que está sempre imóvel, e para a qual a agulha imantada aponta. Então, ele descreve o instrumento utilizado pelos navegantes [11]:

Eles utilizam uma arte que não pode enganar, pela propriedade do magneto, uma pedra marrom e feia, à qual o ferro se une espontaneamente; eles prestam atenção para onde ela aponta. Depois de aplicarem a agulha a ela, e a colocarem em um canudo de palha, pondo-a na água, a palha faz com que ela flutue. Então a ponta gira diretamente para aquela estrela, com tanta certeza que ninguém jamais duvidará e nem se enganará com isso. Quando o mar está escuro e enevoado, não se podendo ver nem as estrelas nem a Lua, eles colocam uma luz junto à agulha e não temem perder seu caminho. A ponta gira para a estrela, e os navegantes são ensinados a seguir na direção certa. É uma arte que não pode falhar.

Devemos notar que no tipo de bússola descrita por Guyot de Provins a agulha magnetizada flutua sobre a água, presa a um canudo de palha. Este parece ser o tipo mais antigo de bússola.

Sabe-se que Guyot esteve na Palestina, no final do século XII. O seu conhecimento sobre a bússola poderia provir de um contato com navegantes do oriente próximo.

O terceiro dos autores considerados mais antigos que escreveram sobre a bússola, Jacques de Vitry, também esteve no Oriente Médio, tendo participado de uma cruzada contra os muçulmanos. Sua descrição sobre a bússola aparece em uma obra sobre a Terra Santa: Historia Orientalis seu Hierosolymitama. A obra parece ter sido completada em torno de 1220, mas algumas de suas partes (incluindo o trecho sobre a bússola) parecem ser dos primeiros anos do século XIII [12].

Existem nas regiões orientais algumas pedras preciosas muito raras e com poderes admiráveis. O adamant é encontrado mais longe, na Índia; tem cor clara e avermelhada. Seu tamanho não excede a parte central de uma avelã. É tão duro que resiste a todos os metais, mas pode ser quebrado pelo quente fresco e quente de um bode. O fogo não o aquece. Atrai o ferro por algum poder oculto. Depois de tocar o adamant, uma agulha de ferro sempre gira para a estrela setentrional [norte], que não se move, como se fosse o eixo do firmamento; as outras sempre giram à sua volta. Por isso ele é realmente necessário aos que navegam no mar. Quando colocado perto de um magneto, ele não permite que aquele atraia o ferro. E se um magneto atrair o ferro e um adamant for aproximado, ele toma o ferro, fazendo com que o magneto lhe ceda sua presa.

Durante a Antiguidade e a Idade Média, a palavra adamant podia significar diamante ou magneto; e supunha-se que um diamante era capaz de impedir um magneto de atrair o ferro, ou podia superar seu poder. Neste texto de Jacques de Vitry há uma evidente confusão entre os dois significados. $\mathrm{O}$ autor não explica como se usa a bússola, apenas afirma que a agulha de ferro aponta para o norte e que isso é útil para os navegantes.

A partir das menções que esses três autores fazem, é possível concluir que no início do século XIII as bússolas já eram bem conhecidas em vários lugares da Europa; eles descrevem tanto a bússola "molhada" (com uma agulha flutuando sobre a água) quando a bússola "seca" (em que a agulha é montada sobre um pino).

Após esses autores, vários outros se referiram à bússola. Citaremos apenas alguns deles. Michael Scot (aprox. 1195-1235) se refere a ela várias vezes, em seus escritos de aproximadamente 1230. Scot era uma pessoa versada em árabe e grego, que em 1217 estava em Toledo, traduzindo para o latim obras de Aristóteles e de Al-Bitruji; posteriormente, traduziu obras de Averroes (Ibn-Rushd). Em torno 
de 1225, estava em Bolonha, participando da corte do Sagrado Imperador Romano Frederick II, que estabeleceu um grupo de estudiosos do conhecimento islâmico. Pode ser que Michael Scot tenha obtido o conhecimento da bússola através dos muçulmanos.

Uma conexão mais direta com os pensadores islâmicos pode ser encontrada na menção que Vincent de Beauvais (aprox. 1190-1264) faz sobre a bússola. No seu Speculum majus, escrito entre 1220 e 1260, ele comentou [13]:

Aristóteles, no seu livro sobre os minerais, diz que o magneto atrai o ferro e que o ferro obedece a esta pedra através de virtudes ocultas, que se movem sem auxílio através de todos os corpos sólidos, assim como através do ar. Um dos seus lados atrai o ferro e o outro o repele. Além disso, o lado que atrai o ferro é atraído para zaron, ou seja, para o norte; o lado oposto é atraído para afon, isto é, para o sul. E o magneto tem essa peculiaridade: se você trouxer o ferro até o lado do magneto que é chamado zaron, que se volta para o norte, ele [o ferro] gira para o norte. E se você levar o ferro para o outro lado, ou seja, para afon, ele se moverá para o sul.

Não existe um Liber de lapidibus escrito por Aristóteles; trata-se de uma obra pseudo-aristotélica composta por um autor islâmico durante a Idade Média. Aproximadamente na mesma época, Albertus Magnus escreveu algo muito semelhante, com a diferença de que utilizou as palavras zoron e aphron, em vez de zaron e afon [14]. Esses dois termos, indicando norte e sul, não são latinos nem gregos. Podem ser originados do árabe, embora a correspondência não seja exata. Segundo Julius Klaproth, zohr ou zohron em árabe indica o sul (e não o norte), daí tendo se originado a palavra sur em espanhol e sul em português. Por outro lado, avr ou avron em árabe indica o norte [15].

A partir de 1250 surgiram muitas referências à bússola em obras poéticas, o que parece indicar que o conhecimento desse instrumento já havia se generalizado entre os europeus [16]. Havia, no entanto, muitas confusões a respeito dos efeitos produzidos pelos dois lados dos magnetos, bem como sobre os seus poderes de atração e repulsão.

\section{Estudos experimentais na Idade Média}

Um passo muito importante no desenvolvimento do magnetismo ocorreu no século XIII, com estudos experimentais que esclareceram vários aspectos que ainda não haviam sido estudados - como a descoberta dos polos magnéticos. Há um documento fundamental que apresenta esse avanço, que é a carta de Petrus Peregrinus sobre o magneto, datada de 1269. É a obra mais antiga que conhecemos onde aparece claramente a ideia de que as pedras magnéticas possuem dois pontos opostos, onde seu poder de atração é mais forte, e que são qualitativamente diferentes um do outro. São explicadas técnicas experimentais para a localização dos polos de uma pedra magnética e sua identificação (polo norte e polo sul), bem como é explicada a atração entre polos opostos e repulsão entre polos do mesmo tipq 2. O próprio uso do nome "polo", aplicado ao magnetismo, que aparece neste texto, parece ser original.

O tratado de Petrus Peregrinus é bastante sofisticado, envolvendo a produção de pedras magnéticas redondas, através de um torno, para o estudo de suas propriedades, sem que estas sejam influenciadas por irregularidades do formato da pedra. Ele faz experimentos com magnetos sobre pratos de madeira flutuando na água, para analisar tanto sua rotação natural quanto os fenômenos de atração e repulsão - uma técnica interessante e que pode ser utilizada didaticamente. Mostra como agulhas de aço podem ser magnetizadas tocando um ímã natural e analisa sua polaridade, estudando sua orientação quando são presas a um pedaço leve de madeira e colocadas para flutuar na água. Estuda o que acontece quando uma pedra magnética é quebrada, mostrando o surgimento de novos polos magnéticos na região da ruptura e indicando que esses polos desaparecem quando a pedra é reconstituída e colada.

Além do estudo dos fenômenos básicos do magnetismo, Petrus Peregrinus se preocupa com a construção de instrumentos de vários tipos. Ele não descreve a construção de bússolas comuns, que já

\footnotetext{
${ }^{2}$ Silvanus Thompson afirmou que esta e outras propriedades dos magnetos já tinham sido descritas por Roger Bacon na sua obra Opus Majus [17]. Esse autor não indicou em que ponto dessa obra de Bacon estariam localizadas as informações que forneceu. Examinando sistematicamente todo o Opus Majus [18], não foi possível localizar nenhum ponto que fundamente as afirmações de Thompson.
} 
existiam antes de seu estudo; propõe instrumentos mais sofisticados. Dois deles contêm o mecanismo da bússola (em um deles, com uma pedra magnética flutuando; no outro, com uma agulha magnética presa a um pino vertical), mas seu objetivo não é encontrar as direções cardeais e sim determinar o azimute do Sol, da Lua e das estrelas. Um dos aparelhos que propõe é um moto perpétuo movido através da força magnética - provavelmente o primeiro desse tipo.

Sob muitos aspectos, o trabalho de Petrus Peregrinus é espantosamente "moderno", pela grande ênfase em experimentos e, também, por não adotar as muitas superstições antigas a respeito dos poderes magnéticos. Por outro lado, algumas de suas ideias eram muito diferentes das que aceitamos hoje em dia. Ele não acreditava que a orientação das bússolas fosse devida ao magnetismo da própria Terra, como nós aceitamos: defende que ela é produzida por um efeito celeste - como havia exposto Messahalla. Um dos dispositivos que descreve apresentaria uma demonstração experimental da influência celeste sobre os ímãs, produzindo uma rotação espontânea de uma pedra magnética redonda, em torno do seu eixo, a cada 24 horas - um fenômeno que não existe. Suas explicações sobre atração e repulsão também são "antiquadas", baseando-se na analogia entre esses fenômenos e as emoções humanas.

Esse texto é o mais antigo tratado que conhecemos dedicado exclusivamente ao estudo do magnetismo. Antes dele, os fenômenos magnéticos eram citados em pequenos trechos de obras sobre outros assuntos. Após o trabalho de Petrus Peregrinus o estudo do magnetismo não teve avanços significativos durante três séculos, tendo sido superado pela publicação da obra de William Gilbert (1600), que foi fortemente influenciada por esse estudo medieval.

\section{Quem foi Petrus Peregrinus?}

Sabe-se muito pouco a respeito desse Petrus Peregrinus, ou Pierre de Maricourt, um dos mais importantes pesquisadores medievais $[19,20]$. Sua obra mais importante e influente que conhecemos, descrita na seção anterior, foi escrita sob a forma de uma carta: "Epistola Petri Peregrini de Maricourt ad Sygerum de Foucaucourt, militem, de magnete" (Carta de Petrus Peregrinus de Maricourt para Syger de Foucaucourt, militar, sobre o magneto).
A partir das próprias indicações dessa obra, sabemos que era natural de Maricourt (ou Maharnecuria), uma pequena vila da Picardia, no norte da França. Era certamente uma pessoa culta, tendo provavelmente estudado em uma universidade. Tinha bons conhecimentos de astronomia, tendo sido autor de um tratado sobre o astrolábio [21]; escreveu uma obra sobre óptica, que não foi conservada; e sua pesquisa sobre os ímãs mostra que estava a par dos conhecimentos de sua época.

A carta de Petrus Peregrinus é dirigida a seu amigo Syger, de Foucaucourt (nome de uma vila próxima a Maricourt). Syger é descrito na carta como militem, isto é, militar, no sentido de alguém que participa de guerras, sendo talvez pertencente à nobreza 3

É evidente que tanto Petrus Peregrinus quanto seu amigo Syger eram pessoas educadas, já que se comunicavam por escrito, em latim. Devemos recordar que nessa época (século XIII) a maioria esmagadora da população europeia, incluindo a nobreza, era analfabeta.

Ignoram-se as datas de nascimento e morte de Petrus Peregrinus. Sabe-se apenas que escreveu sua obra sobre o astrolábio depois de 1261 e que seu tratado sobre magnetismo foi concluído exatamente no dia 8 de agosto de 1269 , pois esta data consta ao final do text4. Quando escreveu essa obra, ele estava participando do cerco à cidade de Lucera (Itália) realizado por Charles d'Anjou, rei da Sicília; portanto, tinha envolvimento com atividades militares. Especula-se que ele poderia ter sido um arquiteto encarregado da fabricação de máquinas de guerra, mas nada de concreto se sabe sobre isso. Conhecemos, por outro lado, o nome de um especialista em armamentos e muralhas que de fato trabalhou para Charles d'Anjou: Pierre d'Angicourt [23].

Devemos notar que nem Peregrinus nem Maricourt são sobrenomes desse autor; apenas conhecemos seu nome próprio, Petrus (ou Pierre, em francês). O epíteto "Peregrinus" não significava um simples peregrino (uma pessoa que fez uma peregrinação religiosa) e sim uma pessoa que participou de uma cruzada contra os muçulmanos. Talvez ele fosse assim chamado apenas por ter participado do

\footnotetext{
${ }^{3}$ Há sugestões de que este Syger poderia ter sido um professor de Paris, Siger de Brabant (aprox. 1240-1284). No entanto, Siger de Brabant não era da Picardia e não era militar [22]. ${ }^{4}$ Apenas três dos cerca de 30 manuscritos da carta mencionam a data, ao final; mas o mais antigo deles tem essa data e ela é aceita como autêntica por todos os historiadores.
} 
cerco a Lucera que, embora fosse uma cidade da Itália, era um importante reduto islâmico. Pode ser, no entanto, que ele tenha também participado de alguma cruzada no Oriente Médio - por exemplo, a sétima cruzada, em 1248, chefiada pelo rei Louis IX, e da qual havia participado Charles d'Anjou ${ }^{5}$

É relevante conhecer um pouco sobre a situação histórica na qual Petrus Peregrinus escreveu sua obra sobre magnetismo.

Desde o século IX os árabes haviam invadido a Sicília, que no início do século seguinte estava quase totalmente nas mãos dos muçulmanos. Essa região permaneceu sob domínio islâmico até a invasão normanda, que se iniciou em 1061 [26]. Porém, somente em 1220-1222 eles foram definitivamente derrotados por Frederick II, Sagrado Imperador Romano. Durante as duas décadas seguintes, Frederick II transferiu a população muçulmana da Sicília para Lucera, para facilitar o seu controle - aproximadamente 15.000 a 20.000 pessoas [27].

Frederick II se interessou pela avançada cultura do mundo islâmico. Estimulou traduções do grego e do árabe para o latim, assim como apoiou o desenvolvimento de estudos de vários tipos, tendo criado uma universidade em Nápoles, em 1224. Embora não tivesse a mesma abrangência que seu contemporâneo Alfonso X, contribuiu para o conhecimento da cultura islâmica. São conhecidas cartas que enviou a pensadores muçulmanos sobre muitas questões científicas e filosóficas. Michael Scot foi seu astrólogo de 1227 até 1236 e traduziu nesse período obras de Avicena (Ibn Sina) e de Averroes (Ibn Rushd). Outros estudiosos e tradutores fizeram parte da corte de Frederick, no período [28].

No início da década de 1260, o grande número de muçulmanos em Lucera começou a representar um perigo tanto religioso quanto militar. Para estimular uma ação contra eles, em 1268 o papa Clemente IV convocou uma cruzada contra Lucera [29]. Charles I, de Anjou, que havia sido coroado rei da Sicília em 1266, organizou o ataque à cidade, que começou no início de 1269, utilizando máquinas de guerra, como catapultas. No entanto, Lucera tinha uma forte defesa, que resistiu aos esforços de tomada. A partir de março desse ano, o exército enviado por Charles d'Anjou cortou a entrada de suprimentos na cidade, iniciando um sítio rigoroso. A partir de

\footnotetext{
${ }^{5}$ Émile Charles afirmou que Petrus Peregrinus participou dessa cruzada, prestando importantes serviços militares a Louis IX [24]; Silvanus Thompson também sugere que isso ocorreu [25].
}

abril, Charles passou a participar pessoalmente do ataque, mas não conseguiu vencer a defesa. A cidade foi derrotada, no entanto, pela falta de alimentos, que era tão rigorosa que seus habitantes tiveram que comer capim. Lucera se rendeu no dia 28 de agosto [30]. Poucas semanas antes, Petrus Peregrinus havia concluído seu tratado sobre magnetismo, enquanto participava do cerco à cidade.

\section{Roger Bacon e "magister Petrus"}

É provável que Roger Bacon (aprox. 1210-1292) tenha conhecido diretamente e sofrido forte influência de Petrus Peregrinus. Há várias passagens de suas obras em que ele se refere de forma muito elogiosa a um certo magister Petrus. Segundo Émile Charles, a pessoa que Bacon admirava como o mais sábio de sua época, admirado como exemplo vivo da verdadeira ciência e que venerava como seu mestre, era mestre Petrus (magister Petrus), o senhor dos experimentos (dominus experimentorum) [31]. Há um trecho do capítulo 13 do Opus tertium no qual Bacon se refere a esse magister Petrus, que pode ser (ou não) Petrus Peregrinus, com as seguintes palavras $[32,33]$ :

Só conheço um que se possa louvar. Pois ele não se preocupa com discursos ou discussões sobre palavras, mas segue as obras da sabedoria e se dedica silenciosamente a elas. E assim, enquanto outros cegos lutam para ver a luz do Sol, como um morcego no crepúsculo, ele próprio a contempla em seu esplendor completo, pois ele é um mestre dos experimentos (dominus experimentorum). Assim, pela experiência, ele conhece as coisas naturais, médicas e alquímicas, todas as coisas nos céus e abaixo deles. Realmente, ele se envergonha se alguma pessoa vulgar, ou anciã, ou soldado, ou rústico do campo sabe algo que ele próprio não conhece. Por isso ele pesquisou todas as operações de fundição de metais e os trabalhos com ouro, prata e outros metais, e todos os minerais; e ele conhece todas as coisas que se referem ao exército, às armas e à caça; e examinou tudo o que se refere à agricultura, medidas de terras, e atividades dos agricultores; e também refletiu sobre os ex- 
perimentos (experimenta), dispositivos e encantamentos de feiticeiras e mágicos, e os truques e ilusões de todos os malabaristas; assim, nada do que se deve saber lhe é oculto; e ele sabe como criticar todas as coisas falsas e mágicas. Assim, sem ele é impossível que a filosofia possa ser completada, ou ser tratada de um modo útil ou certeiro. Porém, assim como seu valor não pode ser estimado, ele não valoriza seu próprio valor. Pois se ele quisesse se relacionar com reis e príncipes, encontraria aqueles que o honrariam e o tornariam rico. $\mathrm{Ou}$, se ele quisesse mostrar em Paris tudo o que conhece, através de suas obras sábias, todo o mundo o seguiria. No entanto, como nesses casos ele seria impedido de se dedicar ao grande volume de experimentos que o encantam, ele negligencia toda honra e riqueza; mais ainda porque ele pode, no momento que quiser, chegar à riqueza por sua sabedoria $a^{6}$ Ele já trabalhou durante três anos em um espelho capaz de queimar a uma certa distância e logo chegará ao seu objetivo, pela graça de Deus. Nenhum dos [autores] latinos $7^{7}$ conseguiria fazer isso, que jamais foi tentado por eles, embora tenhamos livros sobre a composição desses espelhos.

Este elogio foi escrito por Bacon em 1267, ou seja, dois anos antes da carta de Petrus Peregrinus sobre o magnetismo.

As descrições de Bacon concordam, em tudo, com o que sabemos de Petrus Peregrinus: experimentação, construção de aparelhos, estudos sobre óptica e astronomia [34]. Além disso, alguns manuscritos da obra de Roger Bacon identificam essa pessoa como Petrus de Machariscuria, ou de Maharniscuria, ou de Mahariscuria (ou seja, Maricourt); e em um deles, adiciona que é da região de Picardia [34]. Isso torna altamente plausível que o mestre Petrus fosse Petrus Peregrinus.

\footnotetext{
${ }^{6}$ Bacon provavelmente se refere ao conhecimento de magister Petrus sobre alquimia, que lhe permitiria produzir ouro.

${ }^{7}$ Os "latinos" eram, aqui, os pensadores europeus, que escreviam em latim - por oposição aos pensadores islâmicos, que escreviam em árabe.
}

Para Roger Bacon, o mestre Petrus era um matemático perfeito, versado em todas as partes dessa ciência, como a astronomia, a óptica e a ciência da propagação das formas. Era um mestre da experimentação, através da qual contribuiu para a medicina, a alquimia, a astronomia e a óptica. Não era uma pessoa que apenas conhecia livros, mas tinha experiência na fabricação de dispositivos, como um astrolábio esférico que girava sozinho e um grande espelho incendiário [35].

Roger Bacon escreveu em 1267-1268 as obras em que menciona magister Petrus. Lá ele também afirma que vinte anos antes (ou seja, em torno de 1247) havia recebido ensinamentos dessa pessoa, que lhe havia ensinado tudo o que sabia sobre as ciências, proporcionando-lhe a base de sua filosofia e teologia [36]. Mais do que conhecimentos, Bacon parece ter aprendido com seu mestre a estudar a natureza através de experimentos - um método que ambos praticaram e que era uma novidade, na Europa, embora estivesse muito desenvolvido entre os pesquisadores islâmicos: "Apresento os princípios da experiência, que nenhum [autor] latino pode compreender, a não ser um único: a saber, o mestre [magister] Petrus [...]" [37].

Roger Bacon, ao mencionar magister Petrus, nunca se refere a estudos sobre magnetismo; e, inversamente, quando Bacon fala sobre magnetismo, não menciona magister Petrus. Devemos levar em conta que as três obras mais importantes de Roger Bacon (Opus majus, Opus minus, Opus tertium) foram escritas antes da Epistola de magnete [38].

Há um pequeno trecho da Opus minus [39] em que Roger Bacon descreve vários fenômenos magnéticos, como a imantação de um pedaço de ferro (aço) por um ímã, bem como a atração e repulsão do ferro imantado pelos dois lados do magneto - efeitos que também são descritos na Epistola de magnete. Apresenta também um experimento diferente dos de Petrus Peregrinus, no qual um ferro magnetizado flutua na água e se coloca um ímã acima dele, ou abaixo dele (dentro da água), observando seu movimento vertical [40]. Roger Bacon afirma, como Petrus Peregrinus, que as várias partes do céu estão conectadas a vários pontos do magneto (e não apenas os respectivos polos). Alistair Cameron Crombie sugeriu que esses paralelos entre Petrus Peregrinus e Roger Bacon tornam extremamente provável que exista alguma dependência de um em relação ao outro [41]; mas não é possível determinar quem in- 
fluenciou e quem foi influenciado. De qualquer forma, pode-se afirmar com segurança que o Opus minus de Bacon teve mínima influência, pois só é conhecido um único manuscrito desse texto: Oxford, Bodleian Library, MS Digby 218 [42] que só foi publicado no século XIX; enquanto a Epistola de magnete teve ampla circulação.

É difícil saber qual a formação e quais as influências recebidas pelo próprio Petrus Peregrinus. É razoável supor-se que estudou em uma universidade e havia adquirido uma cultura científica muito ampla. No entanto, sua abordagem experimental não era adotada nas universidades, nessa época. Pode ter sido, em grande parte, autodidata; pode ter sido influenciado pela tradição experimental islâmica, que era muito forte, desde o século XI. Seu interesse pela óptica sugere que teria estudado as obras islâmicas sobre o assunto, que tiveram grande influência na Europa no século XIII; e seu tratado sobre o astrolábio - uma das primeiras obras europeias sobre o assunto - também indica uma familiaridade com os estudos islâmicos sobre esse assunto.

O testemunho de Bacon sugere que Petrus Peregrinus poderia ter obtido conhecimentos práticos sobre magnetismo com navegantes, já que ele tentava aprender tudo o que podia com pessoas externas ao círculo universitário. Teria tido contato com pilotos muçulmanos, na época do cerco a Lucera? Infelizmente, faltam informações adicionais a respeito do que ele estudou e sobre pessoas que possam tê-lo influenciado.

\section{A influência do tratado de Petrus Peregrinus}

Sabemos que o tratado sobre magnetismo de Petrus Peregrinus circulou durante a Idade Média sob a forma de manuscrito por toda a Europa. Foram conservadas pelo menos 31 cópias manuscritas de seu trabalho. Um dos primeiros autores que reproduz quase todas as ideias de Petrus Peregrinus (sem indicar o seu nome) foi Hendrik Bate (aprox. 12461310), no capítulo 13 da parte XX de seu Speculum divinorum et quorundam naturalium, escrito entre 1285 e 1305 [43]. Aproximadamente em 1300, Jean de Saint-Amand (aprox. 1262-1312), em uma obra médica, Expositio Joannis a Sancto Amando supra antidotarium Nicolai, também reproduziu muitas ideias da Epistola de magnete [44]. Em 1326, Thomas Bradwardine, professor da Universidade de Ox- ford, se referiu ao trabalho de Petrus Peregrinus. Depois da invenção da imprensa de tipos móveis, a obra foi publicada em 1558, em Augsburg, por Achilles Gasser [45]. Em 1562, Jean Taisnier plagiou o trabalho de Petrus Peregrinus, sem citar seu nome, no livro Opusculum perpetua memoria dignissimum, de natura magnetis et ejus effectibus. Item de motu continuo [46].

Muitos autores que escreveram sobre magnetismo antes de William Gilbert foram fortemente influenciados pela obra de Petrus Peregrinus: Girolamo Fracastoro (1478-1553), Girolamo Cardano (1501-1576), Georg Hartmann (1489-1564), Robert Norman (séc. XVI), William Barlow (1544-1629). O próprio trabalho sobre magnetismo de William Gilbert [47], que citou Petrus Peregrinus várias vezes, reproduz muitos resultados da Epistola de magnete. Não há dúvidas de que a metodologia experimental de Gilbert, que fez grande sucesso na época, foi fortemente influenciada pela abordagem de Petrus Peregrinus.

A obra de Gilbert, muito mais completa do que a de seu predecessor medieval, contribuiu para eclipsála. Além disso, apesar da publicação da Epistola de magnete em meados do século XVI, esse livro não teve grande difusão, tornando-se rapidamente uma obra rara [48]. Por outro lado, em sua maioria os resultados obtidos por Petrus Peregrinus logo se tornaram aceitos por todos, incorporados ao conhecimento geral sobre magnetismo, sem que as pessoas soubessem quem havia escrito pela primeira vez sobre eles. Thomas Browne deu o devido crédito a Petrus Peregrinus, citando o seu tratado sobre o magneto, mas supondo tratar-se de um autor do século XV [49]. Athanasius Kircher utilizou e elogiou a Epistola de magnete, mas afirmou que alguns consideravam que tinha sido escrita por Roger Bacon [50] - uma opinião que já havia sido apresentada por William Gilbert [51]. William Cave, em sua história da literatura eclesiástica, também atribuiu a obra a Roger Bacon [52]. Durante o século XVII, vários autores se referiam a Petrus Peregrinus apenas para descrever suas contribuições questionáveis, como a esfera magnética que gira sozinha em 24 horas e seu moto perpétuo [53, 54, 55].

Durante o século XVIII ainda havia uma falta de reconhecimento do trabalho de Petrus Peregrinus, até 1795, quando o físico Tiberio Cavallo (nascido na Itália, mas que vivia na Inglaterra) tomou conhecimento de um manuscrito da Epistola de magnete existente em Leyden. Ele conseguiu uma cópia do 
manuscrito e publicou várias partes dela, com a tradução para o inglês, na segunda edição de seu livro A treatise on magnetism [56 $]^{8}$. No entanto, o manuscrito de Leyden tinha o título incompleto: em vez de "Epistola Petri Peregrini de Maricourt ad Sygerum de Foucaucourt, militem, de magnete", o copista havia escrito "Epistola Petri Adsigerii, in signationibus naturae magnetis" [57], levando Cavallo a atribuir essa obra a um suposto "Peter Adsiger". Tiberio Cavallo procurou informações sobre esse suposto autor, localizando então a informação sobre um manuscrito existente em Genebra, com o título "Epistola Petri Peregrini de Maricourt ad Sygerum de Foucaucourt, militem, de magnete" e concluiu que talvez o destinatário do manuscrito de Genebra fosse o autor do manuscrito de Leyden, sugerindo que algum historiador investigasse melhor o assunto [58].

Essa confusão perdurou por algumas décadas. Em 1837, o físico Sir David Brewster escreveu para a Encyclopadia Britannica um longo artigo sobre magnetismo, no qual se referiu tanto à obra de Petrus Peregrinus quanto à carta de Peter Adsiger, que considerava distintas [59]. Devemos compreender que, nessa época, tanto a localização quanto o acesso aos manuscritos e obras raras era muito difícil, o que justifica esses equívocos.

A confusão sobre "Peter Adsiger" foi resolvida de forma definitiva pelo físico holandês Willem Wenckebach, que estabeleceu a inexistência desse suposto autor e esclareceu que Petrus Peregrinus era o autor da Epistola de magnete [60,61]. Tendo localizado, através de catálogos impressos, oito manuscrito dessa obra, em diferentes países, Wenckebach pediu a alguns pesquisadores que lhe fornecessem mais informações sobre os mesmos; um de seus contatos foi o historiador da ciência Guglielmo Libri, que vivia em Paris. Motivado por esse contato, Libri se interessou pelo assunto, sendo um dos primeiros historiadores a estudar a Epistola de magnete. Ele reproduziu o tratado de Petrus Peregrinus a partir de um único manuscrito existente em Paris, com muitas lacunas e erros [62].

Três décadas depois, o padre Timoteo Bertelli publicou um estudo extraordinariamente detalhado e profundo sobre Petrus Peregrinus, no qual incluiu a primeira edição crítica do texto latino, a partir de sete manuscritos que consultou [63]. O texto

${ }^{8}$ Quase todos os autores mencionam a terceira edição do livro, de 1800 . latino foi também publicado por Gustav Hellmann [64], que se baseou principalmente no trabalho de Bertelli.

Charles Sanders Peirce planejou publicar uma edição em latim da Epistola de magnete, acompanhada por uma tradução e comentários; publicou um folheto de 16 páginas com sua proposta [65], mas desistiu do projeto por não conseguir apoio financeiro para o mesmo. Em 1900, o antiquário Bernard Quaritch publicou uma reprodução facsimilar de um manuscrito da obra de Petrus Peregrinus [66].

No início do século XX foram publicadas duas traduções da obra de Petrus Peregrinus para o inglês, uma delas realizada por Silvanus Thompson [67] e a outra pelo Irmão Arnold (Joseph Charles Mertens) [68]. Esta segunda tradução, embora tenha muitas falhas, foi reproduzida por Edward Grant no seu livro Source book on medieval sciences, tornando-se a mais conhecida [69].

Apesar de quase dois séculos de estudos históricos, a obra de Petrus Peregrinus continua a ser pouco conhecida por parte dos cientistas e professores. Isso é lamentável, pois o desconhecimento da sua contribuição ajuda a perpetuar o grave equívoco de que, durante a Idade Média, todos apenas repetiam os ensinamentos antigos e ninguém se dedicava ao estudo experimental. Sob o ponto de vista educacional e cultural, é importante divulgar o trabalho de pesquisadores medievais, tanto europeus quanto islâmicos, que deram importantíssimas contribuições à ciência, para superar o preconceito existente sobre esse período da história.

\section{Carta de Petrus Peregrinus, de Maricourt, ao cavalheiro Sieger de Foucaucourt, sobre o magneto}

Este tratadd $9^{9}$ sobre o magnetd ${ }^{10}$ contém duas partes, das quais a primeira se compõe de dez capítulos, e a segunda de trêst11. O primeiro capítulo da primeira parte mostra a intenção da obra; o segundo, qual deve ser o artífice dessa obra; o terceiro, sobre o conhecimento da pedra; o quarto, sobre a ciência $[$ scientia] da descoberta das partes da pe-

\footnotetext{
${ }^{9}$ Embora esta obra seja descrita como uma "carta", fica evidente que ela não é uma correspondência pessoal e sim um tratado, dividido em partes e capítulos.

${ }^{10}$ Preferimos adotar o termo "magneto" do que "ímã", nesta tradução, para seguir mais de perto o original em latim.

${ }^{11}$ Este preâmbulo do texto de Petrus Peregrinus só aparece em alguns manuscritos.
} 
dra; o quinto, sobre a ciência da descoberta dos polos na pedra, e qual deles é norte, qual é sul12. o sexto, como um magneto atrai um magneto; o sétimo, como o ferro, tocado com um magneto, gira para os polos do mundo; o oitavo, como o magneto atrai o ferro; nono, por que o lado norte atrai o sul, e vice-versa; o décimo questiona de onde o magneto recebe a virtude natural que possui. Os capítulos da segunda parte são estes: primeiro capítulo, sobre a construção de um instrumento para conhecer o azimute do Sol e da Lua, e de qualquer outra estrela, no horizonte; o segundo, sobre a construção de outro instrumento melhor, para a mesma finalidade; o terceiro, sobre a construção do artifício de uma roda com movimento perpétuo.

\section{PARTE I}

\section{Capítulo 1. Sobre a intenção da obra}

Querido amigo, interrogado por você sobre a virtude oculta na pedra magnética, eu lhe revelarei isso através de uma narrativa grosseira 13 De fato, nada é agradável aos olhos dos filósofos sem o princípio do conhecimento; e a natureza dos bens se oculta nas trevas e se obscurece, até que ela se eleva nos raios da dedução comum. Portanto, pela amizade por você, redigirei em uma linguagem clara aquilo que é desconhecido completamente pelos estudiosos vulgares. Nós apresentaremos nesta carta a ciência do que se mostra nesta pedra; e depois de expor isso, haverá uma parte do tratado na qual ensinaremos como construir instrumentos de física; aquilo que está oculto na pedra se relaciona à arte de esculpir a pedra.

\footnotetext{
${ }^{12} \mathrm{O}$ texto latino se refere sempre ao norte como "setentrional" e ao sul como "meridional". No entanto, nesta tradução, utilizamos os termos usuais, "norte" e "sul". A palavra latina septentriones, que significa norte, está associada às sete estrelas mais brilhantes da constelação da Ursa Maior, que eram comparadas a sete bois (septem triones) que giravam em torno do eixo de um moinho [70]. Uma reta imaginária que une duas delas ( $\alpha$ e $\beta$ ) aponta para o polo norte celeste; por isso, eram muito utilizadas pelos navegantes. Por causa dessa origem astronômica do norte geográfico, nos antigos mapas e nas mais antigas rosas-dos-ventos utilizadas nas bússolas, o norte era muitas vezes indicado por uma estrela, ou por um grupo de sete estrelas [71].

${ }^{13}$ No original latino, o autor utiliza a segunda pessoa do singular ("tu") para se referir ao seu amigo. Nesta tradução, utilizamos o tratamento informal "você".
}

Embora eu chame de manifestos 14 os efeitos sobre os quais você me interrogou, eles serão, apesar disso, incompreensíveis e, para os vulgares, como ilusões e fantasmas. É por isso que, para a multidão, eles são secretos; mas para os astrólogos e para os que estudam a natureza, serão manifestos; e para eles, serão um conforto, e para os viajantes experientes serão uma ajuda não desprezível. A partir disso se compreenda a intenção deste tratado.

\section{Capítulo 2. Que qualidades deve ter o artífice para esta obra}

Saiba, caríssimo, que o artífice desta obra deve conhecer a natureza das coisas e não deve ignorar os movimentos celestes, mas deve ser igualmente hábil em trabalhos manuais, para que possa mostrar efeitos maravilhosos por sua obra ${ }^{15}$. Pois por sua habilidade ele poderá rapidamente corrigir um erro, enquanto que isso jamais aconteceria apenas pela ciência natural e pela matemática, se lhe faltasse habilidade manual. Pois nas obras ocultas, precisamos muito de habilidade manual e, muitas vezes, sem ela não conseguimos completar nada; há muitas coisas submetidas ao império da razão que não podemos realizar pelas mãos.

E assim, portanto, mostra-se a qualidade que deve ter o artífice para esta obra.

\section{Capítulo 3. Sobre o conhecimento da pedra}

Deve-se reconhecer essa pedra [lapis $]^{16}$ por quatro características, a saber, cor, homogeneidade, peso e virtude. Sua cor deve ser como do ferro branco, misturado com cor celeste ou índigo, como do ferro polido que foi corrompido pela infecção do ar. Nunca vi uma pedra assim que não produzisse um grande efeito. Elas são encontradas principalmente nas regiões do norte, sendo trazidas pelos navegantes em todos os portos do mar do norte, como os da Normandia, da

\footnotetext{
${ }^{14} \mathrm{O}$ autor está distinguindo os efeitos, que são observáveis ou manifestos, das suas causas, que são ocultas.

${ }^{15}$ Petrus Peregrinus associava os fenômenos magnéticos aos céus, como será visto mais adiante; por isso, ele indica aqui a importância do conhecimento da astronomia nesse estudo. Ele também se refere à necessidade de ter habilidade técnica ou manual, para poder realizar os experimentos e construir os dispositivos que descreve. A ênfase que ele dá a essa habilidade manual é pouco comum na Europa durante o século XIII, embora fosse enfatizada por autores islâmicos anteriores, como Ibn al-Haytham.

${ }^{16}$ Ao longo de toda a obra, quando Petrus Peregrinus se refere à "pedra", ele está indicando a pedra magnética natural.
} 
Picardia e de Flandres ${ }^{17}$. Esta pedra deve também ser de uma substância homogênea, pois a que possui manchas vermelhas e buracos em alguns lugares não deve ser escolhida; mas dificilmente se encontra um magneto totalmente livre dessas falhas ${ }^{18}$. Uma pedra tal que, por sua homogeneidade e compactação de suas partículas, é tornada pesada, tem um valor de peso. Quanto à sua virtude, pela forte atração sobre o ferro de grande peso; adiante explicarei o modo dessa atração. Então, quando você encontrar uma pedra com essas características, trate de adquiri-la, se puder.

Assim, portanto, se esclarece por quais características é possível conhecer tal pedra.

\section{Capítulo 4. Sobre a ciência da descoberta das partes da pedra}

Você deve saber que esta pedra produz em si uma semelhança com o céu, e adiante ensinarei como provar isso claramente pela experiência. E assim como no céu há dois pontos mais notáveis do que os outros - aqueles em torno dos quais a esfera celeste gira como sobre um eixo, dos quais um se chama polo ártico ou norte; o outro, antártico ou su ${ }^{19}$ - do mesmo modo você deve entender que há na pedra dois pontos, um norte, o outro sul20. Para descobrir

\footnotetext{
${ }^{17}$ Maricourt, o local de origem de Petrus Peregrinus, fica na região da Picardia, no norte da França. Já que ele indica que os marinheiros que frequentavam os portos da Picardia traziam tais pedras magnéticas, isso sugere que ele já estava familiarizado com elas muito antes de escrever este tratado.

${ }^{18} \mathrm{~A}$ importância de que a pedra magnética seja homogênea aparece em alguns pontos do tratado, como no capítulo 10 da primeira parte.

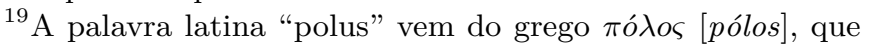
significa eixo de rotação; foi depois utilizada também para as extremidades de um eixo, pelo menos desde Aristóteles [72]. Durante a Antiguidade, supunha-se que as estrelas estavam presas em na esfera celeste, e que esta girava em torno de um eixo. Os polos celestes seriam as extremidades do eixo em torno do qual a esfera celeste girava. Segundo o sistema astronômico geocêntrico, a Terra estaria parada e, portanto, não teria um eixo de rotação e não possuía polos; apenas o céu tinha polos. Aquilo que chamamos de polo terrestre norte era descrito, antigamente, como sendo o ponto sob o polo norte, já que o polo norte pertencia ao céu.

${ }^{20}$ Como o magneto não gira, ele não possui eixo e não tem polos no sentido etimológico da palavra. Os polos de uma pedra magnética foram assim designados por analogia com os polos do céu e por causa da relação (defendida por Petrus Peregrinus) entre a orientação magnética e os polos celestes. Este parece ser o primeiro uso da palavra "polo" associada ao magnetismo [73].
}

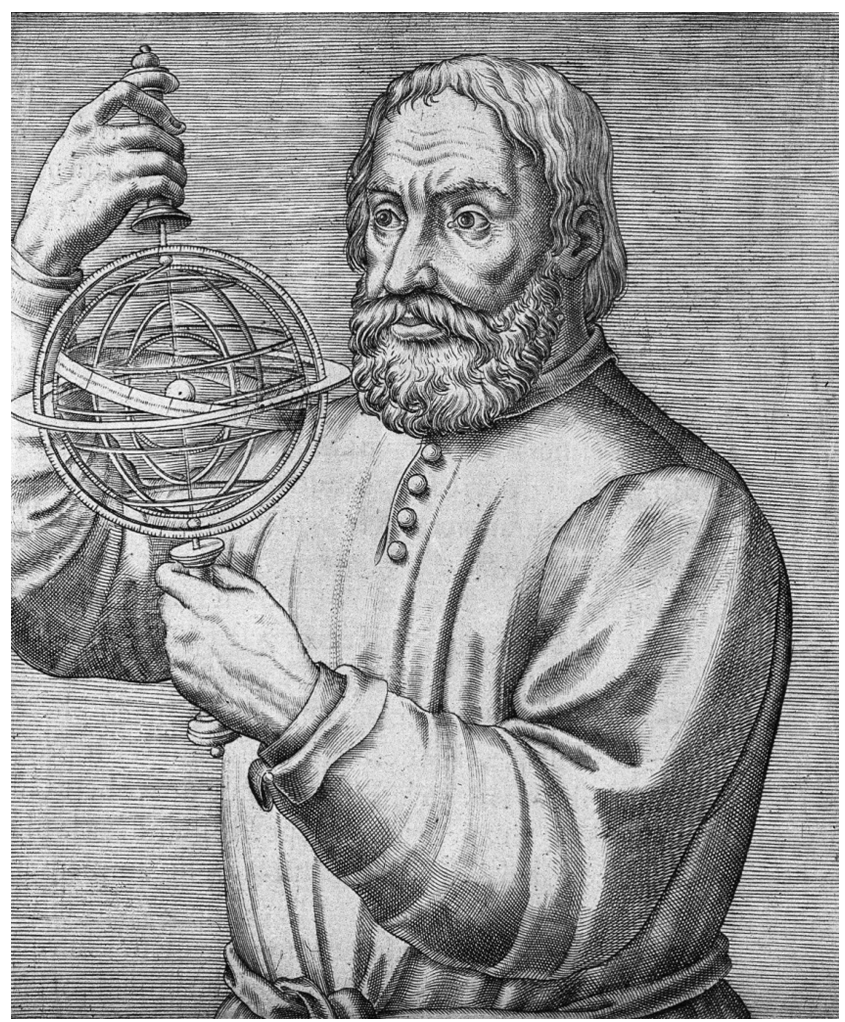

Figura 1: Gravura de 1584, representando Johannes de Sacrobosco, autor medieval da famosa obra astronômica "Tratado da Esfera". Sacrobosco está segurando uma esfera armilar, que representa a estrutura do universo no sistema geocêntrico. A esfera central é a Terra, e a estrutura mais externa representa a esfera das estrelas, que gira em torno da Terra. As mãos de Sacrobosco seguram suportes contendo pinos que representam os polos celestes. (Fonte: Wellcome Library, London, ICV No 3315; licença: Creative Commons)

esses dois pontos de forma gera 21 podem ser usadas diversas técnicas.

Um modo consiste em torná-la redonda com o dispositivo com o qual se tornam redondos os cristais e outras pedras ${ }^{22}$ e depois deve ser colocada uma agulha, ou ferro comprido como uma agulha ${ }^{23}$, sobre

\footnotetext{
${ }^{21}$ Primeiramente, o autor indicará como são localizados os polos, sem a preocupação de identificar qual deles é norte e qual é sul ("descobrir esses dois pontos de forma geral"); depois, mostrará o modo de identificá-los.

${ }^{22}$ Trata-se de um torno que possa ser utilizado com materiais duros - diferente, por exemplo, dos que são utilizados para tornear madeira. A ideia de produzir uma esfera magnética, aqui apresentada por Petrus Peregrinus, parece ser nova, tendo sido depois muito utilizada por William Gilbert em sua famosa obra sobre o magnetismo, publicada em 1600.

${ }^{23}$ Petrus Peregrinus não esclarece a diferença entre ferro e aço, que é muito importante. William Gilbert, nos capítulos 6 e 7 da primeira parte de sua obra sobre magnetismo [74], esclareceu a diferença entre ferro e aço, explicando que apenas o segundo é capaz de conservar efeitos magnéticos fortes.
} 


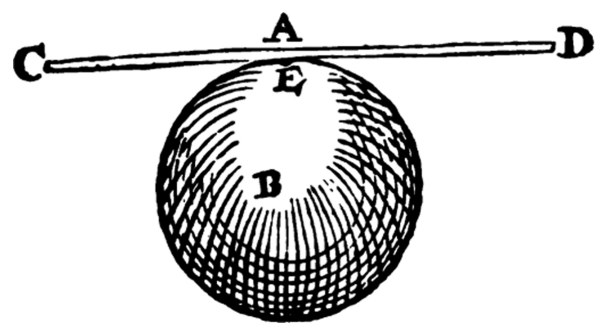

Figura 2: Para procurar a posição dos polos de uma pedra magnética redonda, Petrus Peregrinus indicou que deve ser colocada uma agulha ou pedaço comprido de ferro equilibrado sobre a esfera; então, a agulha ou ferro se moverá, adquirindo uma direção que será influenciada pela posição dos polos magnéticos da esfera [75].

a pedra ${ }^{24}$ e deve-se traçar uma linha sobre a pedra, dividindo-a ao meid 25 depois, deve ser colocada a agulha ou ferro em outro local sobre a pedra ${ }^{26}$ e traçar uma linha sobre a pedra, na direção exata do ferro; e se quiser, poderá fazê-lo em diversos locais ou sítios; sem dúvida alguma, todas essas linhas convergirão em dois ponto 27 assim como todos os meridianos da esfera do mundo convergem para dois polos opostos do mundd 28 . Saiba então que um é norte e o outro sul, cuja prova você verá no capítulo seguinte.

Há outro modo para descobrir esses dois pontos que é melhor; na pedra tornada redonda, como foi dito, você deve ver o lugar onde a ponta de uma agulha ou ferro adere mais frequentemente ou forte-

Quando um objeto de ferro (por exemplo: um pedaço de arame) está em contato (ou está próximo) de um ímã, ele também se torna magnético; mas quando separado, perde praticamente todo seu poder magnético. Um objeto de aço, pelo contrário (como uma agulha de costura), conserva o magnetismo por um longo tempo.

${ }^{24}$ Como a pedra magnética utilizada neste experimento tem forma redonda, trata-se de equilibrar a agulha ou fio metálico sobre sua parte superior, conforme mostrado na Fig. 2. Esse método não poderia ser utilizado se a pedra magnética tivesse uma forma irregular.

${ }^{25}$ Isso significa traçar um círculo máximo sobre a superfície da esfera, seguindo a direção indicada pela agulha ou pelo ferro.

${ }^{26}$ Para fazer isso, será necessário girar a esfera, escolhendo outro ponto na sua parte de cima, onde será novamente equilibrada a agulha ou o pedaço de ferro, para observar a sua nova direção.

${ }^{27}$ Ver Fig. 3, que esclarece esse método para encontrar os polos magnéticos da pedra. Muitos comentadores recentes afirmam que Petrus Peregrinus apresentou, neste ponto, um modo de determinar as linhas de força do corpo magnético. Isso é uma interpretação anacrônica.

${ }^{28}$ Os meridianos, antigamente, eram considerados círculos celestes (e não sobre a superfície da Terra), que passavam pelos polos do céu. Alguns meridianos celestes podem ser vistos na esfera armilar mostrada na Fig. 1.

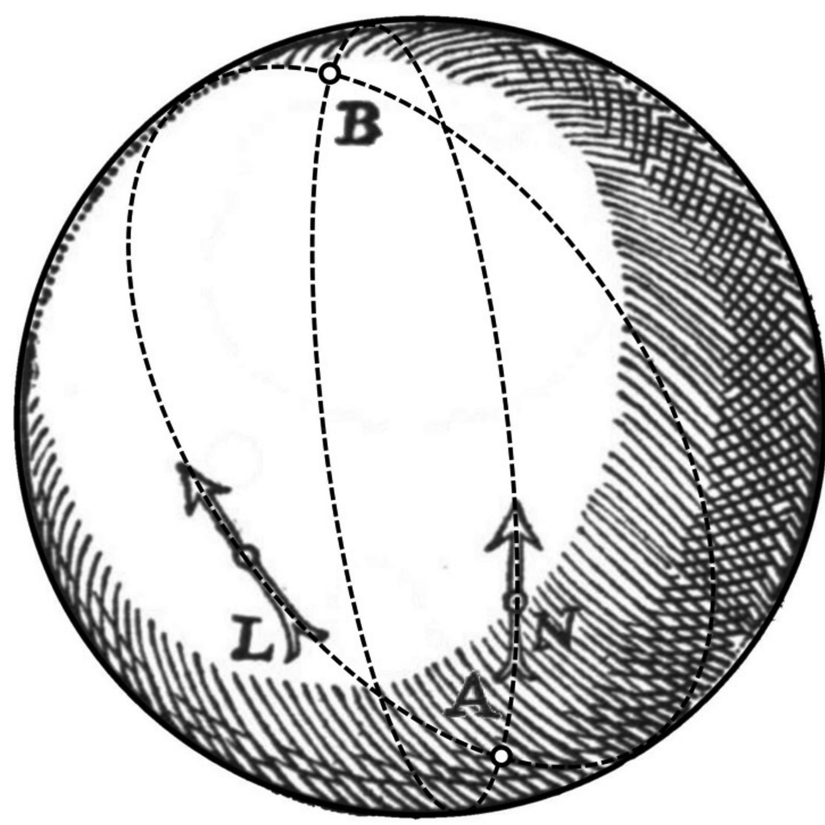

Figura 3: Utilizando uma agulha ou pedaço comprido de ferro colocado em dois ou mais pontos sobre a superfície da esfera magnética, Petrus Peregrinus traça os círculos máximos que indicam a direção tomada por esses indicadores; a intersecção desses círculos (pontos A e B, nesta figura) indicam as localizações dos dois polos magnéticos. Fonte da imagem: ilustração criada a partir de uma figura de William Gilbert [76].

mente; então este lugar é um dos pontos descobertos pelo método descritd 29

Para encontrar esse ponto precisamente na pedra, quebre um pequeno pedaço da agulha ou ferro, que seja oblongo e com a espessura [comprimento] de duas unhas [unguis $]$, e coloque-o sobre o lugar naquele ponto que foi encontrado do modo já dito; e se ficar perpendicular sobre a pedra, esse é sem dúvida o ponto desejado; se não, mova-o até que fique perpendicular ${ }^{31}$ Isso feito, assinale esse ponto; e de modo semelhante, encontre no lado contrário da pedra o ponto oposto. Se fizer isso corretamente, e se

\footnotetext{
${ }^{29}$ Esse segundo método procura a localização dos polos através da propriedade de atração (e não de direcionamento da agulha). A força de atração é mais forte nos polos magnéticos.

${ }^{30} \mathrm{~A}$ unha (unguis, em latim) era uma unidade de medida correspondente a meia polegada. Embora o texto fale sobre a espessura do pedaço de ferro, provavelmente se trata do seu comprimento. Utiliza-se um pedaço de ferro (ou de agulha) pequeno, nesse método, para que o seu peso não tenha grande influência no experimento.

${ }^{31}$ Como o peso do pedaço de ferro ou de agulha não é nulo, ele só ficará perpendicular à superfície da esfera magnética se o polo magnético estiver na sua parte superior; se estiver em um dos lados, isso não ocorrerá. Ver Fig. 4, que ilustra este método.
} 


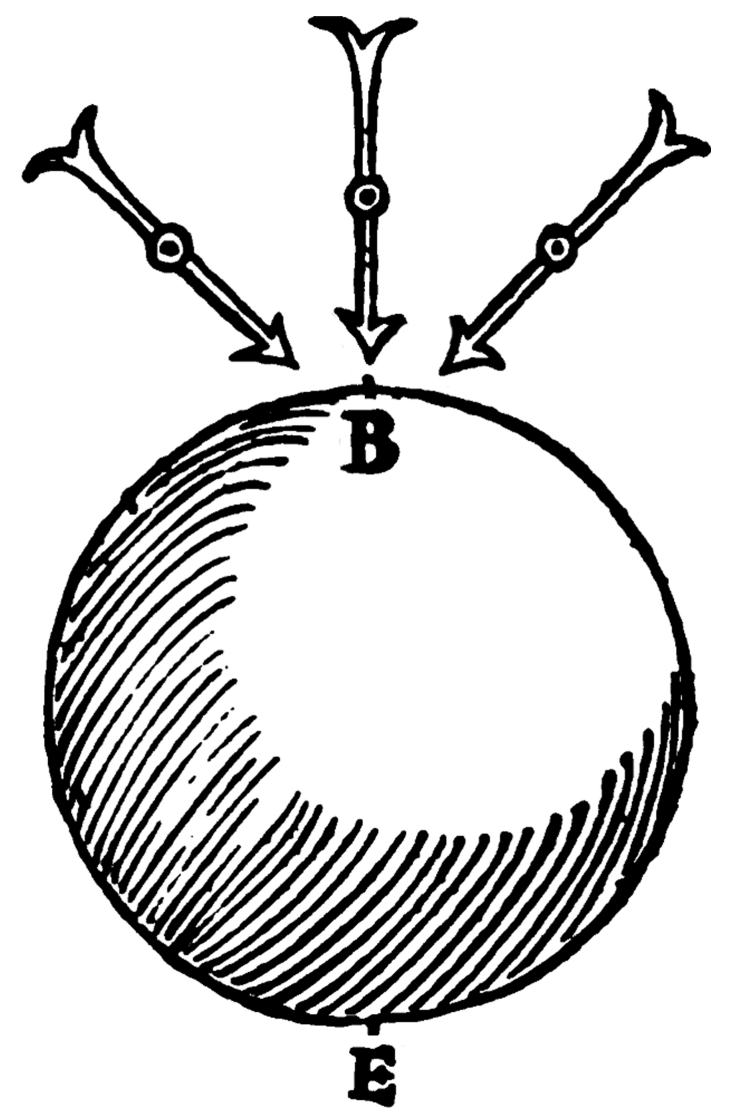

Figura 4: Terceiro método para encontrar a posição dos polos da esfera magnética: procurar os pontos onde um pequeno pedaço de ferro ou de agulha fica em posição perpendicular à superfície da pedra magnética. Fonte da imagem: ilustração criada a partir de uma figura de William Gilbert [77].

a pedra for homogênea e escolhida, os pontos estarão diretamente opostos, como os polos na esfera ${ }^{32}$.

\section{Capítulo 5. Sobre a ciência da descoberta dos polos na pedra: qual deles é norte e qual é sul}

Tendo visto a arte de conhecer os polos da pedra genericamente ${ }^{33}$ pode-se conhecer qual é norte e qual sul por este modo: tome um recipiente redondo de madeira, como um prato ou uma travessa, e

\footnotetext{
${ }^{32}$ Os polos de uma esfera são, como já foi explicado, as extremidades do eixo em torno do qual a esfera gira. São dois pontos diametralmente opostos. Como a esfera magnética não está girando, ela não tem eixo de rotação e não tem polos, no sentido etimológico. Trata-se, novamente, de uma comparação. No caso da esfera magnética, se ela não for perfeitamente homogênea, os polos magnéticos não estarão em pontos diametralmente opostos.

${ }^{33}$ Os três métodos apresentados no capítulo anterior permitem localizar onde estão os dois polos, mas não indicam qual é o polo magnético norte e qual o polo magnético sul.
}

coloque dentro dele a pedra, de tal modo que os dois pontos da pedra sejam equidistantes da borda do vasd ${ }^{34}$ então coloque [o prato], com a pedra lá colocada, dentro de outro vaso maior cheio de água, de modo que a pedra no primeiro recipiente seja como um marinheiro em um barco; e o primeiro recipiente deve estar no segundo de modo espaçoso, como um barco flutuando em um rio; e digo de modo espaçoso, para que o seu contato com a borda do recipiente maior não impeça o movimento natural da pedra ${ }^{35}$. Pois essa pedra, assim colocada, fará o seu recipiente pequeno girar até que o polo norte da pedra fique na direção do norte do céu, e o sul [da pedra] na direção do sul [do céu 36 ,

Mesmo se ela for deslocada mil vezes, ele retornará mil vezes à sua posição, por um instinto natura 37 E como os lados norte e sul do céu são conhecidos, tornam-se assim conhecidos na pedra, pois cada parte da pedra fica na direção de sua parte do céu.

\section{Capítulo 6. Como um magneto atrai um magneto}

Tendo conhecimento de qual polo, na pedra, é norte, e qual sul, marque os polos com sinais para que possam ser distinguidos sempre que necessário. E se você quiser depois ver como a pedra atrai uma [outra] pedra, tome duas pedras preparadas como foi dito e empregue-as deste modo: coloque uma em seu recipiente para que flutue como o marinheiro no barco; e os seus pontos [polos] que foram descobertos

\footnotetext{
${ }^{34}$ Pressupõe-se que a reta que une os dois polos magnéticos, que já foram encontrados, deve ficar em posição horizontal; e que a pedra magnética deve ficar no meio do prato de madeira.

${ }^{35}$ Neste e em outros pontos do texto, percebe-se que Petrus Peregrinus tem realmente prática na realização desses experimentos e conhece quais detalhes podem facilitá-los ou dificultá-los. Se o prato de madeira contendo a pedra magnética for quase do tamanho do recipiente maior, ele vai esbarrar nas suas bordas e não vai girar, impedindo então a observação do fenômeno descrito. Ver Fig. 5.

${ }^{36}$ De acordo com a nomenclatura atualmente utilizada, o lado da pedra magnética que aponta para o norte seria considerado como o polo magnético SUL (e não norte), e vice-versa. Utilizamos essa nomenclatura porque consideramos que a orientação da pedra magnética flutuante (ou de uma bússola) se dá através da interação com os polos magnéticos da Terra (que Petrus Peregrinus não conhecia) e porque consideramos que os polos que se atraem são os opostos. Porém, a nomenclatura utilizada por Petrus Peregrinus não é absurda; ela simplesmente parte de um outro ponto de vista, chamando de polo magnético norte o que aponta para o norte; ver Fig. 6.

${ }^{37}$ Em alguns manuscritos encontra-se "pelo poder de Deus", em vez de "por instinto natural".
} 


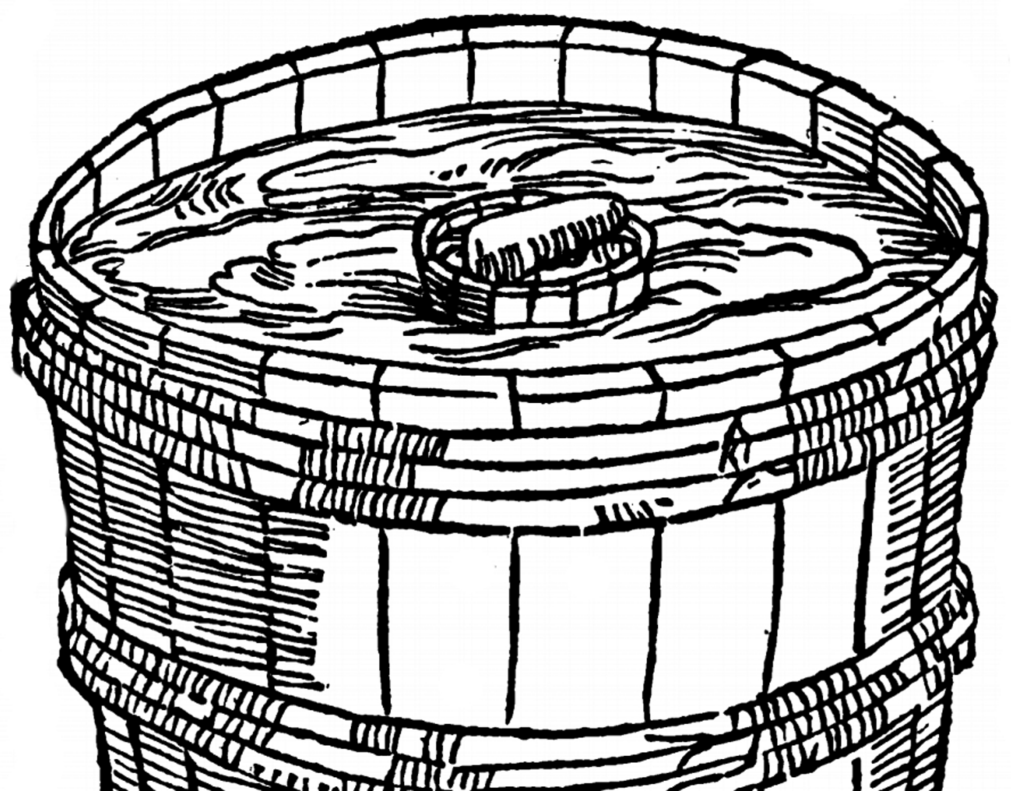

Figura 5: Para identificar os polos da pedra magnética, ela é colocada dentro de um prato ou travessa de madeira, que flutua dentro de outro recipiente bem maior, com água. Nesta ilustração a pedra magnética não é redonda; Petrus Peregrinus descreve o experimento com a pedra em forma esférica [78].
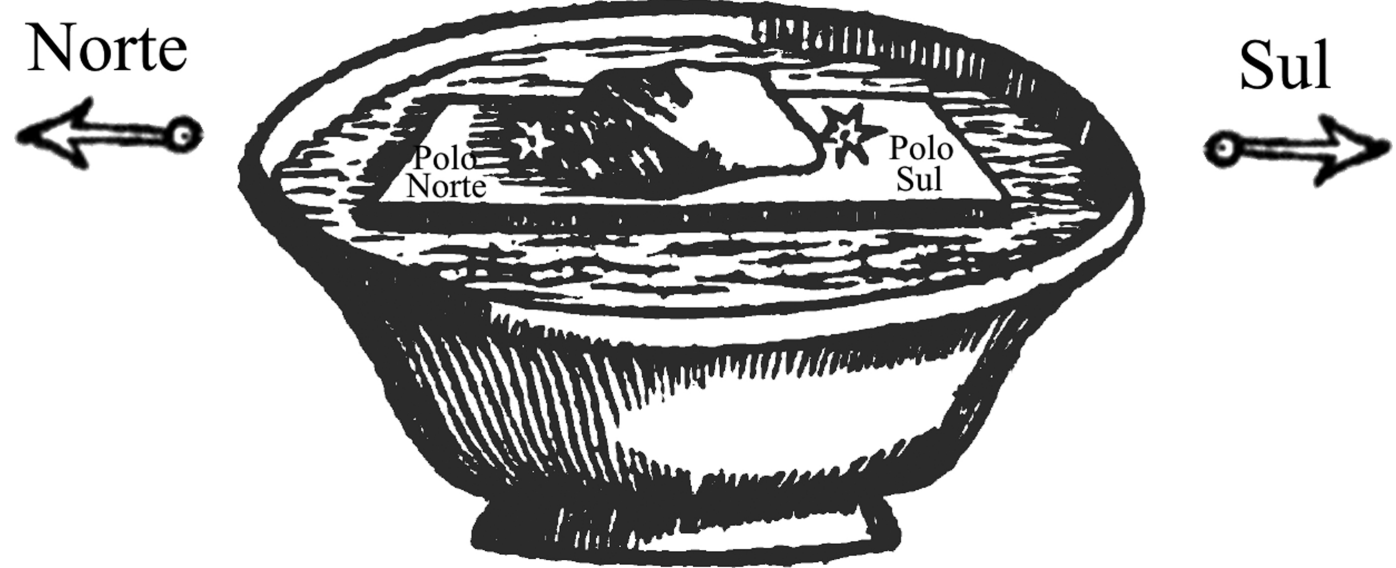

Figura 6: De acordo com a interpretação oferecida por Petrus Peregrinus, o polo sul da pedra flutuando na água aponta para a direção sul; e o polo norte da pedra aponta para o norte. Isso é o oposto de nossa nomenclatura atual. Imagem adaptada da obra de Athanasius Kircher [79], com pequenas modificações.

devem estar equidistantes do horizonte ou da borda do recipiente, o que dá na mesma 38 . Mantenha na mão a outra pedra. E aproxime o lado norte da pedra que segura da parte sul da pedra que está flutuando no recipiente; a pedra que flutua seguirá a pedra que você segura, como se quisesse se unir a ela. E a mesma coisa acontecerá se, inversamente, você apresentar a parte sul da pedra que segura à parte norte da pedra que flutua, ou seja, a que flutua

\footnotetext{
${ }^{38} \mathrm{Ou}$ seja: a reta que une os dois polos deve estar na posição horizontal.
}

seguirá a pedra que você segura. Saiba, portanto, como regra, que a parte norte da pedra atrai a parte sul em outra pedra, e a sul [atrai] a norte 39 . Mas se você fizer o inverso, quer dizer, se aproximar a norte da norte, a pedra que você segura na mão colocará em fuga a pedra que flutua; e se aproximar a sul da sul, o mesmo acontece; e isso é porque a parte norte atrai [appetit] a sul; e por isso vemos a norte fugir;

\footnotetext{
${ }^{39}$ Esta é a apresentação mais antiga que conhecemos da lei de atração dos polos magnéticos opostos.
} 


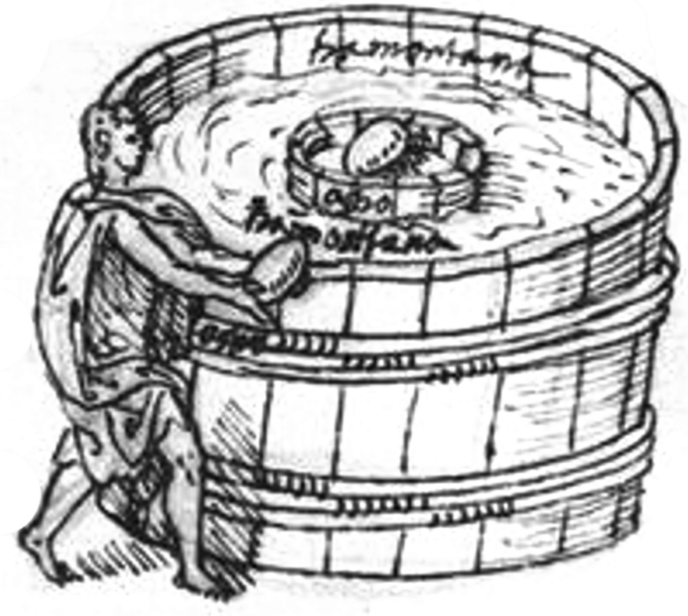

Figura 7: Experimento descrito por Petrus Peregrinus, para observar a atração ou repulsão entre duas pedras magnéticas: uma delas flutua na água e a outra está na mão do experimentador. Fonte da imagem: manuscrito de Filippo Pigafetta (1533-1604), com tradução da obra de Petrus Peregrinus; reproduzido na edição das obras de Petrus Peregrinus por L. Sturlese e R. B. Thomson [80].

e a evidência [signum] é que ela se une de forma semelhante à sul 40 .

E a recíproca ocorrerá com o outro lado, ou seja, com o sul, que se for apresentado ao sul da pedra que flutua, você verá esta fugir; o que não ocorreria, como foi dito, com a parte norte [aproximada] para a sul. E isso elimina a presunção de alguns que dizem que se a escamônea [Convolvulus scammonea] atrai a bílis por causa da semelhança, então o magneto [atrai] o magneto, mais do que o ferro ${ }^{41}$. eles supõem que isso é falso, embora seja verdadeiro, como aparece no experimento [experimento].

\footnotetext{
${ }^{40}$ Esta última descrição não é muito clara, mas parece poder ser interpretada da seguinte forma. Quando se aproxima o lado norte da pedra que está na mão do experimentador do lado norte da pedra que flutua, ela inicialmente "fugirá" (se afastará); porém, ela geralmente irá girar na água, de tal modo que o lado norte fique mais distante e o lado sul mais próximo, e então será atraída pela pedra que está na mão, unindo-se a ele. A repulsão do norte pelo norte é "explicada" pela atração entre o norte e o sul.

${ }^{41}$ Esta comparação aparece, por exemplo, na obra de Averroes ou 'Abū l-Walid Muhammad Ibn 'Aḥmad Ibn Rušd (11261198), que se baseava em Galeno: "Se a natureza da escamônea, por exemplo, é atrair a bílis, a natureza das pedras magnéticas é atrair apenas o ferro" [81]. Encontramos uma comparação semelhante no comentário de Alfredus Anglicus, ou Alfred of Sareshel (aprox. 1175-1245) à Meteorologia de Aristóteles: "sicut magnes ferrum, scamonea choleram attrahunt" [82].
}

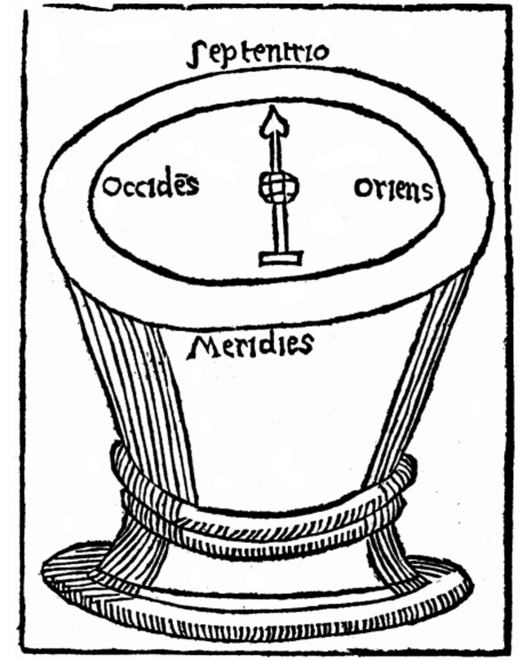

Figura 8: Quando uma agulha de aço é magnetizada e colocada para flutuar na água (presa a um pedaço de madeira, por exemplo), ela gira e indica a direção norte-sul (setentrional-meridional), ficando perpendicular à direção leste-oeste (oriente-ocidente). Nós interpretamos isso como um efeito do campo magnético da Terra, mas Petrus Peregrinus explicava o fenômeno como devido a uma influência dos polos celestes [83].

\section{Capítulo 7. Como o ferro, tocado por um magneto, gira para os polos do mundo}

É bem sabidq 42 por todos os que têm experiência [expertis] que quando um ferro oblongd 43 foi tocado por um magneto, e é colocado sobre uma madeira leve ou sobre palha e posto sobre a água, um lado se moverá para a estrela chamada dos navegantes, porque está perto do pold44. embora na verdade ela não se mova para essa estrela, mas para o polo, e apresentaremos a prova disso no seu capítulo; o outro lado se move para o outro lado do céu.

Quanto a qual parte do ferro gira para qual parte do céu, saiba que a parte do ferro que tocou a parte sul da pedra girará para a parte norte do céu. E inversamente, a parte do ferro que tocou a parte norte da pedra, girará para a parte sul do céu 45

\footnotetext{
${ }^{42}$ As bússolas flutuantes eram conhecidas na Europa desde o século XII e Petrus Peregrinus reconhece que não está descrevendo nada de novo, nesta parte de seu tratado.

${ }^{43} \mathrm{O}$ experimento não funcionará se for utilizado "ferro doce", como um pedaço de arame; ele funciona se for utilizado um pequeno pedaço de aço, como uma agulha de costura, por exemplo.

${ }^{44}$ Petrus Peregrinus adotou a interpretação (proposta por pensadores islâmicos) de que a agulha magnética flutuante gira para a direção norte-sul por uma influência celeste.

${ }^{45}$ No processo de magnetização por toque, se a agulha de aço estiver inicialmente desmagnetizada, então a ponta que tocar
} 
E isso é uma coisa maravilhosa para os que não entendem a causa do movimento do ferro; mas a experiência [experientia] verdadeiramente provou que o que dissemos é exato.

\section{Capítulo 8. Como o magneto atrai o ferro}

Porém, se de acordo com a tendência natural [naturalem appetitum] da pedra, você quiser atrair [attrahere] um ferro que flutua ou nada sobre a água ${ }^{46}$. olhe para o lado norte do ferro e aproxime dele a parte sul da pedra, pois ele então a seguirá. Ou, inversamente, aproxime da parte sul do ferro a parte norte da pedra, pois ela o atrairá sem resistência. Mas se você fizer o inverso, aproximando da parte norte do ferro a [parte] norte da pedra, você verá o ferro fugir, até que a parte sul do ferro se una [à pedra]; e de modo semelhante, deve-se entender a mesma coisa sobre o outro lado.

Se, pelo contrário, for feita uma violência às partes, ou seja, a parte sul do ferro, que foi tocada com a parte norte da pedra, for tocada com a parte sul da pedra; ou a que foi tocada com a sul, e que assim se chama norte no ferro, for unida ao norte da pedra, então o poder [virtus] do ferro será facilmente invertido e aquele [lado] que era norte nele [no ferro] se tornará sul, e inversamente 47 e a causa disso é que a última impressão do agente, confundindo e alterando o poder do primeiro.

\section{Capítulo 9. Por que o lado norte atrai o sul e vice-versa}

O lado norte da pedra atrai o sul, e inversamente, como foi dito. Nessa atração, a pedra que tem o poder mais forte é o agente; e a mais fraca, o paciente 48 Isso se produz pela seguinte causa: o agente realmente pretende não apenas assimilar a si próprio

o polo norte da pedra magnética se tornará um polo sul, e vice-versa.

${ }^{46}$ Petrus Peregrinus já havia descrito a lei de atração e repulsão entre os polos de uma pedra magnética; aqui ele descreve as mesmas leis, porém entre os polos de uma agulha de aço imantada e um magneto. A regra de atração e repulsão é a mesma; mas só se sabe disso pela experiência, pois a priori a interação entre o aço e o magneto poderia ser diferente da interação entre dois magnetos.

${ }^{47} \mathrm{O}$ efeito ocorre, realmente, se a pedra magnética for suficientemente forte para inverter a polaridade anterior do "ferro" (aço).

${ }^{48} \mathrm{O}$ termo "paciente" significa, originalmente, uma pessoa (ou coisa) passiva, sobre quem outra pessoa (ou coisa) atua (o agente, ativo).
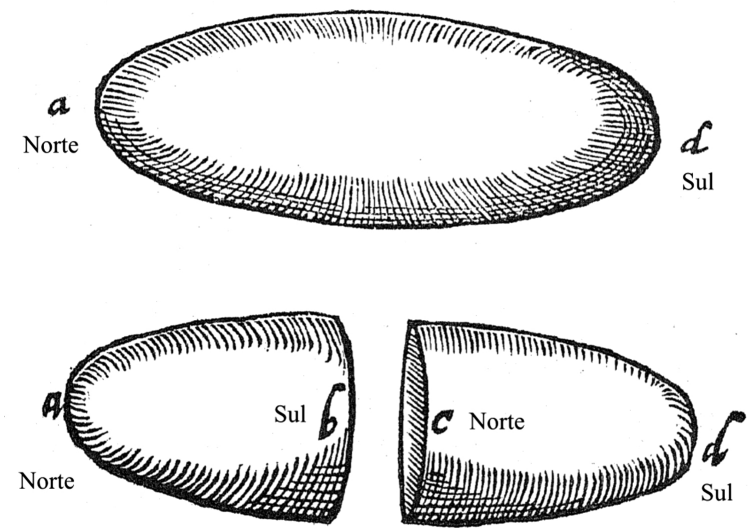

Figura 9: Petrus Peregrinus descreve o surgimento de novos polos, quando uma pedra magnética é dividida em duas. Imagem adaptada a partir da obra de William Gilbert [84]; adicionamos as palavras "norte" e "sul".

seu paciente, mas unir-se, de modo que o agente e o paciente produzam uma só coisa 49 E você pode ter a experiência disso nesta pedra maravilhosa, deste modo. Tome uma pedra [magnética] que será indicada por $\mathrm{AD}$, na qual $\mathrm{A}$ é o [lado] norte e $\mathrm{D}$ o sul; e divida-a em duas partes, fazendo dela duas pedras; depois, coloque na água para flutuar a pedra que contém A; você verá que [o lado] A gira para o norte, como anteriormente. Portanto, a fratura não impede as propriedades da parte da pedra, se for homogênea; e, portanto, é necessário que a parte desta pedra, na sua fratura, que indicaremos por B, seja [um polo] sul 5 .

Portanto, esta pedra de que falamos agora, deve ser representada por $\mathrm{AB}$. Quanto à outra pedra, que contém $\mathrm{D}$, se for colocada na água, será visto que D é [um polo] sul como antes, pois gira para o sul, quando colocada na água. O outro lado, no local da

\footnotetext{
${ }^{49}$ Neste ponto, Petrus Peregrinus apresenta uma interpretação antropomórfica da atração magnética, através de uma comparação com sentimentos dos seres humanos. Embora ele não se refira explicitamente a um homem e uma mulher, parece estar pensando sobre esse tipo de situação. É relevante notar que a palavra "ímã", que utilizamos em português, vem do francês "aimant", que significa "amante"; a comparação entre a atração magnética e a atração sexual é muito antiga.

${ }^{50}$ Se um dos lados da pedra aponta para o norte, a outra apontará para o sul; mas não é evidente que tenha surgido um polo magnético nesse lado. Para estabelecer o efetivo surgimento de um novo polo no ponto em que a pedra é quebrada, seria necessário verificar se existe nessa região um ponto onde a atração é máxima; ou tornear essa metade da pedra magnética e aplicar os testes indicados por Petrus Peregrinus no início do tratado.
} 
fratura, é [um polo] norte, que chamaremos de C; portanto, esta pedra é CD.

Seja a primeira pedra $\mathrm{AB}$ o agente e $\mathrm{CD}$ o pacient ${ }^{51}$ como você vê, as duas partes [B e C] das duas pedras que, antes da separação, eram contínuas em uma única pedra, após a separação, uma se tornou norte, a outra sul. Se aproximarmos de novo as duas partes, uma atrairá a outra, até que elas se unam no ponto $\mathrm{BC}$ onde ocorreu a fratura; portanto, naquilo que depende da tendência [appetitu] natural, formam um só corpo, como antes; e a evidência disso é que se forem coladas, terão os mesmos efeitos que produziam antes 52

Portanto, como você vê pelo experimento, o agente tende a se unir ao seu paciente; e isso se faz por causa da semelhança entre eles53. Portanto, ocorre que, como B se une a $\mathrm{C}$ pelo poder da atração, forma-se uma linha com o agente e o paciente, segundo esta ordem: $\mathrm{ABCD}$, onde $\mathrm{BC}$ são um só ponto; e nessa união são conservadas as identidades das extremidades, à semelhança do que eram antes. Portanto, A é norte na linha completa, assim como era na dividida; do mesmo modo, D é sul, como era no próprio paciente dividido, assim como é nele mesmo unido; B e C, realmente, se tornam idênticos.

E o mesmo ocorre se A for unido com D, para que duas linhas formem uma, sendo a atração o poder de sua união, conforme esta ordem: CDAB, onde DA são um ponto. Assim permanecerá a identidade das extremidades, como anteriormente, antes da união: C será um ponto norte e B sul, como B e C eram antes, quando dividido $\$ 5$.

Mas for feito o contrário, essa identidade ou semelhança das partes não será mantida. Pois você vê que se $\mathrm{C}$ for unido a $\mathrm{A}$, o que é contrário à verdade demonstrada, para que se forme uma linha a partir

\footnotetext{
${ }^{51}$ Neste parágrafo, o autor retoma a análise antropomórfica da atração magnética. É claro que não há nenhum motivo para atribuir a uma das metades o papel de agente (ativo) e à outra metade o papel de paciente (passivo).

${ }^{52}$ Está implícita a ideia de que os dois polos B e C que haviam surgido na quebra vão desaparecer ou se neutralizar mutuamente quando as duas metades da pedra forem reunidas.

${ }^{53} \mathrm{Na}$ verdade, não são os polos iguais que se unem; portanto, este comentário é inválido.

${ }^{54}$ Não é evidente, de forma alguma, que a inversão de posição dos dois pedaços da pedra produza um conjunto que tem dois polos em suas extremidades. À primeira vista, poderia parecer que os dois polos opostos originais (A e D) se anulariam e que a pedra poderia, agora, não ter mais nenhum polo. Para estabelecer se os polos C e B realmente existem, seria necessário fazer o conjunto flutuar sobre a água e observar se ele se orienta na direção norte-sul.
}

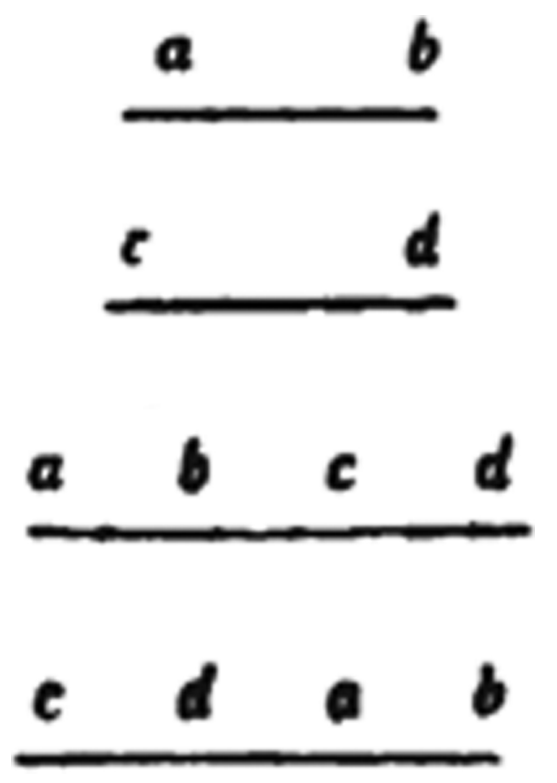

Figura 10: Os manuscritos da carta de Petrus Peregrinus possuem, neste ponto, um diagrama simples, apresentando a sequência dos polos magnéticos.

das duas linhas nesta ordem: BACD, para que A C sejam um só ponto; $\mathrm{D}$, que antes de ser unido era sul, exige nessa linha inteira que $\mathrm{B}$, a outra extremidade, seja norte; porém, antes era sul; isso faz desaparecer a identidade ou semelhança anterior. Mas se você considerar B como sul, como era antes da união, seria exigido que $\mathrm{D}$, a outra parte, fosse norte, embora fosse sul; e assim também não é mantida a identidade ou semelhança. Portanto, é necessário que aquilo que foi convertido de dois em um seja da mesma espécie que o agente; mas assim não seria se a natureza escolhesse isso, que é impossível. Da mesma forma, ocorreria outro inconveniente se você juntar D com B para fazer uma linha, de acordo com esta ordem: ABDC, como é evidente. A natureza, que tende ao ser, e age do melhor modo que pode, escolhe a primeira ordem de ação, na qual se conserva melhor a identidade do que na segunda.

A partir disso fica evidente, portanto, por que a parte sul atrai a norte, e inversamente; e por que, de acordo com a natureza, o sul de modo algum atrai o sul, nem o norte [atrai] o norte 55 .

\footnotetext{
${ }^{55}$ É claro que o autor não explicou o motivo pelo qual os polos opostos se atraem e os iguais se repelem; mas este capítulo do tratado apresentou diversos fenômenos importantes, relacionados com o surgimento de novos polos nos magnetos que são quebrados em duas partes.
} 


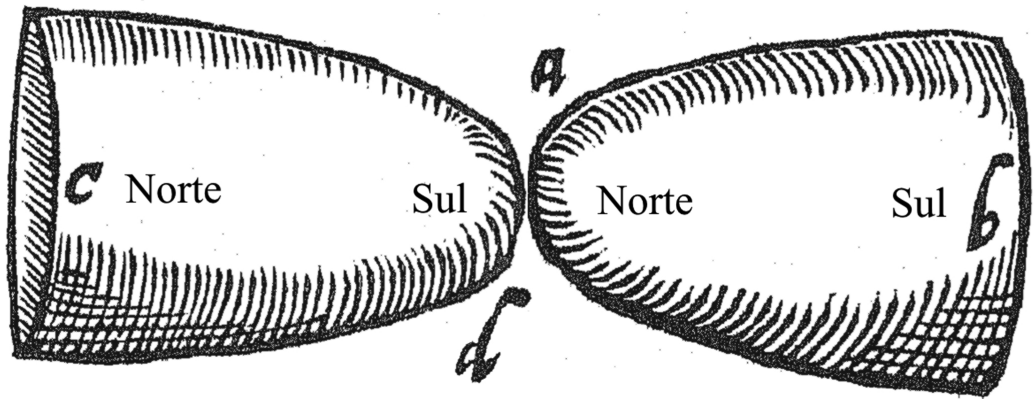

Figura 11: Esta é a segunda forma "natural" de unir os dois fragmentos da pedra magnética. Imagem adaptada a partir da obra de William Gilbert [84], com adição das palavras "norte" e "sul" e troca da posição das duas partes da pedra.

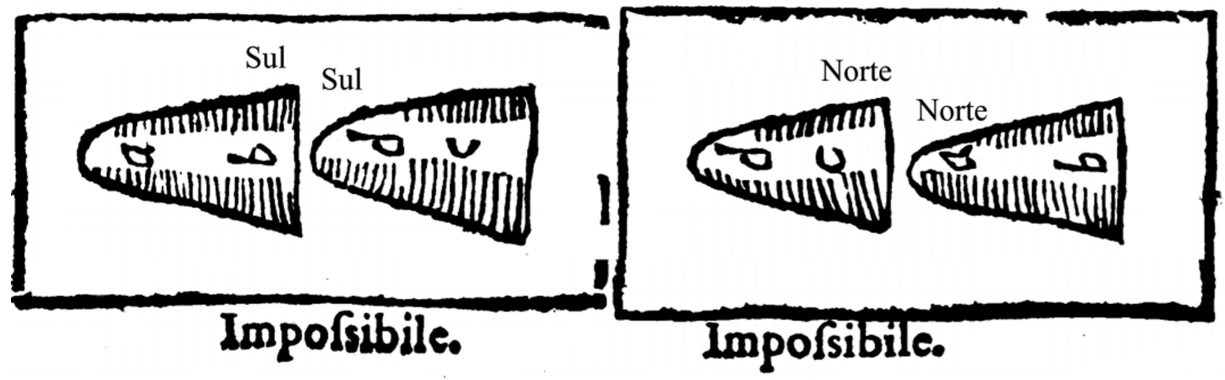

Figura 12: Formas "impossíveis" (ou contrárias à natureza) de unir os dois fragmentos da pedra magnética [85].

\section{Capítulo 10. Investigações sobre de onde o magneto recebe a virtude natural que possui}

Certos pesquisadores fracos [quidam debiles inquisitores] pensaram que o poder pelo qual o magneto age sobre o ferro existisse nos locais dos minerais em que se encontra o magneto; e por isso dizem que, embora o ferro se mova para os polos do mundo, isso não ocorre senão porque há minas dessas pedras situadas naqueles lugare ${ }^{56}$. Eles ignoram que essa pedra é encontrada em diversas partes do mundo, e disso se seguiria que [os magnetos] deveriam se mover para diversos lugares do mundo, o que é falso. E também ignoram que os locais sob os polos são inabitáveis, pois durante a metade do ano lá é dia, e metade noite ${ }^{57}$ assim, deve-se considerar ilusório

\footnotetext{
${ }^{56}$ Aqui, Petrus Peregrinus está criticando autores anteriores (que ele não identifica) que tinham defendido a ideia de que a orientação das pedras magnéticas e das agulhas magnetizadas era devida à presença de grandes concentrações de minérios magnéticos na região polar da Terra. Encontramos tal ideia no poema "Madonna, il fino amore ch'io vi porto" de Guido Guinicelli (falecido em 1276), que afirma: "Naqueles lugares sob a estrela polar / há montanhas de magneto / que transmitem ao ar a virtude / de atrair o ferro; embora distante, / a pedra semelhante tem a capacidade / de adotar esse poder / e direcionar a agulha para a estrela" [86].

${ }^{57}$ Essa característica da região polar era conhecida, a partir da análise astronômica teórica, desde a Antiguidade. No século
}

que os magnetos nos pudessem ser trazidos desses lugares.

Além disso, como o ferro ou a pedra gira tanto para o sul quanto para o norte, como é evidente pelo que já foi dito, precisaríamos supor que um poder influi nos polos da pedra, não só do lado norte, mas também do sul, mais do que de um lugar com minérios. Uma indicação evidente disso é que, esteja onde uma pessoa estiver, ela vê com seus próprios olhos o movimento desta pedra, na direção de seu meridiano celest ${ }^{58}$. Ora, todos os meridianos celestes convergem para os polos do mundo; portanto, é dos polos do mundo que os polos dos magnetos recebem seu poder 59

XIII, tal fato era bem conhecido, graças à obra Tractatus de sphæra, de Johannes de Sacrobosco.

${ }^{58}$ Nesta época, ainda não se sabia na Europa que em geral as bússolas não indicam exatamente a direção norte-sul, podendo ter desvios para leste e para oeste. Os chineses já sabiam disso muitos séculos antes [87] mas o fenômeno só foi registrado pelos europeus na primeira metade do século XV [88, 89].

${ }^{59}$ Notemos a insistência do autor com relação à causa celeste da orientação dos magnetos e das agulhas magnéticas. O argumento que ele apresenta aqui é inválido; mesmo se os corpos magnéticos se orientassem sempre na direção dos meridianos, isso não indicaria qual a causa de tal orientação. Da mesma forma, é inválido argumentar que, já que as bússolas se orientam (aproximadamente) na direção norte-sul, a causa da orientação das bússolas é a existência dos polos magnéticos terrestres. 


\section{Elbumẩar oe nagnis pintuctionibus: annoy rcuolutiöibus:ac coy profe, ctionibus:octo ptinés tractatus.}

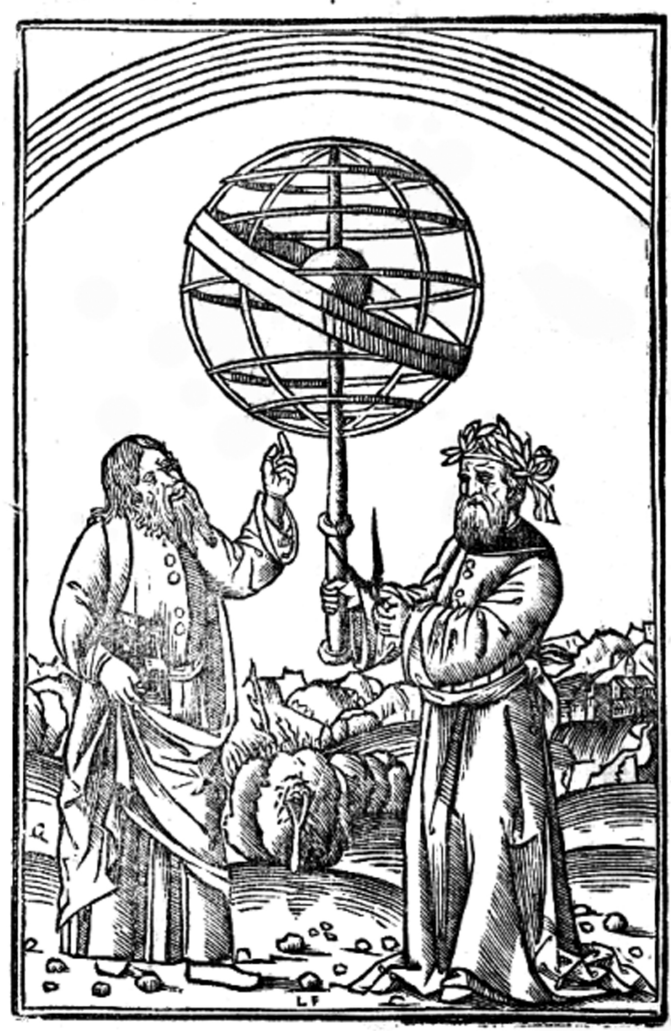

Figura 13: Segundo a concepção geocêntrica do universo, que era aceita na época de Petrus Peregrinus, é a esfera celeste que tem polos e meridianos, e não a Terra. (Fonte da imagem: Albumasar, 1515, folha de rosto)

E a partir disso se torna manifesto que não é movido pela estrela dos navegantes [stella nautica 60 . já que os meridianos celestes não convergem para ela; e sim pelos polos. De fato, a estrela dos navegantes está fora do meridiano, seja em que região for, exceto duas vezes em uma rotação completa do firmamento. Por isso se torna manifesto que as partes do magneto recebem sua virtude dos lugares do céu.

De forma semelhante, pode-se avaliar que as outras partes da pedra sofrem uma influência das outras partes do céu; estime que não apenas os polos da pedra recebem influência dos polos do mundo, mas que a pedra toda [recebe influência] de todo o céu. $\mathrm{Eu}$ o aconselho a fazer o experimento da seguinte forma. A pedra deve ser tornada redonda e seus polos devem ser encontrados nela; depois, coloque a

\footnotetext{
${ }^{60}$ Os navegantes se orientavam, à noite, observando a posição da estrela polar, que fica próxima ao polo celeste norte. Eles sabiam, no entanto, que essa estrela não ficava exatamente na posição do polo celeste.
}

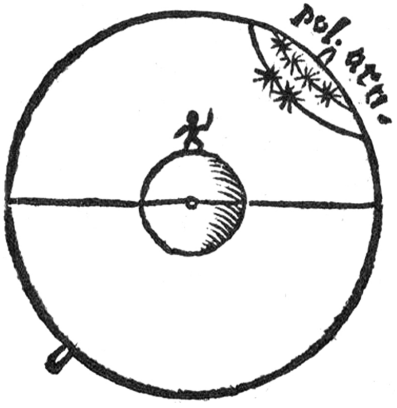

Figura 14: O polo celeste norte é o ponto em torno do qual giram as estrelas, sob o ponto de vista de um observador terrestre [90].

pedra sobre duas pontas agudas, de modo que em cada polo uma ponta esteja fixada ligeiramente na pedra, nesse ponto, para que a pedra possa se mover sobre eles sem dificuldade. Feito isso, examine se as partes da pedra possuem igual peso, girando-a levemente sobre essas pontas; e faça isso diversas vezes, e em diferentes horas do dia, dedicando-se sabiamente.

Isso feito, coloque a pedra no meridiano celeste sobre suas pontas, fixadas de leve nos polos da pedra, para que possa se mover, como uma [esfera] armilar, de modo que a elevação e depressão dos seus polos esteja como a elevação e depressão dos polos celestes, na região em que você estiver.

E se então a pedra se mover seguindo o movimento do céu, alegre-se por ter descoberto um segredo maravilhosd 61 mas se não ocorrer, deve-se atribuir a culpa desse defeito à sua imperícia, e não à natureza 62 . Além disso, considero que nessa posição ou lugar, o poder da pedra é conservado mais propriamente, e que nas outras posições em relação ao céu seu poder é enfraquecido ou obscurecido, em vez de conservado. Através desse instrumento será

\footnotetext{
${ }^{61}$ Embora não o afirme diretamente, o autor quer indicar que a esfera magnética girará, por influência celeste. A ideia é que cada ponto do magneto (e não apenas os seus polos) está conectado a uma região da esfera celeste; como esta gira, o magneto também deve girar. William Gilbert tentou realizar esse experimento, sem sucesso: "Eu omito aquilo que Petrus Peregrinus afirma constantemente, que uma terrella [magneto esférico] suspensa no meridiano pelos seus polos se move circularmente realizando uma rotação inteira em 24 horas: o que não nos foi possível observar até agora [...]" [92]. ${ }^{62}$ Este curioso comentário indica que Petrus Peregrinus não aceitava uma evidência experimental contrária como uma refutação de sua ideia: se o experimento não der certo, é culpa do experimentador, que foi inepto.
} 


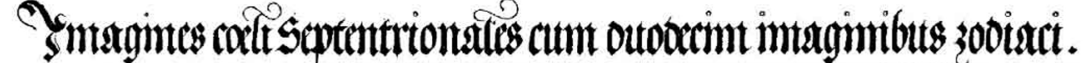
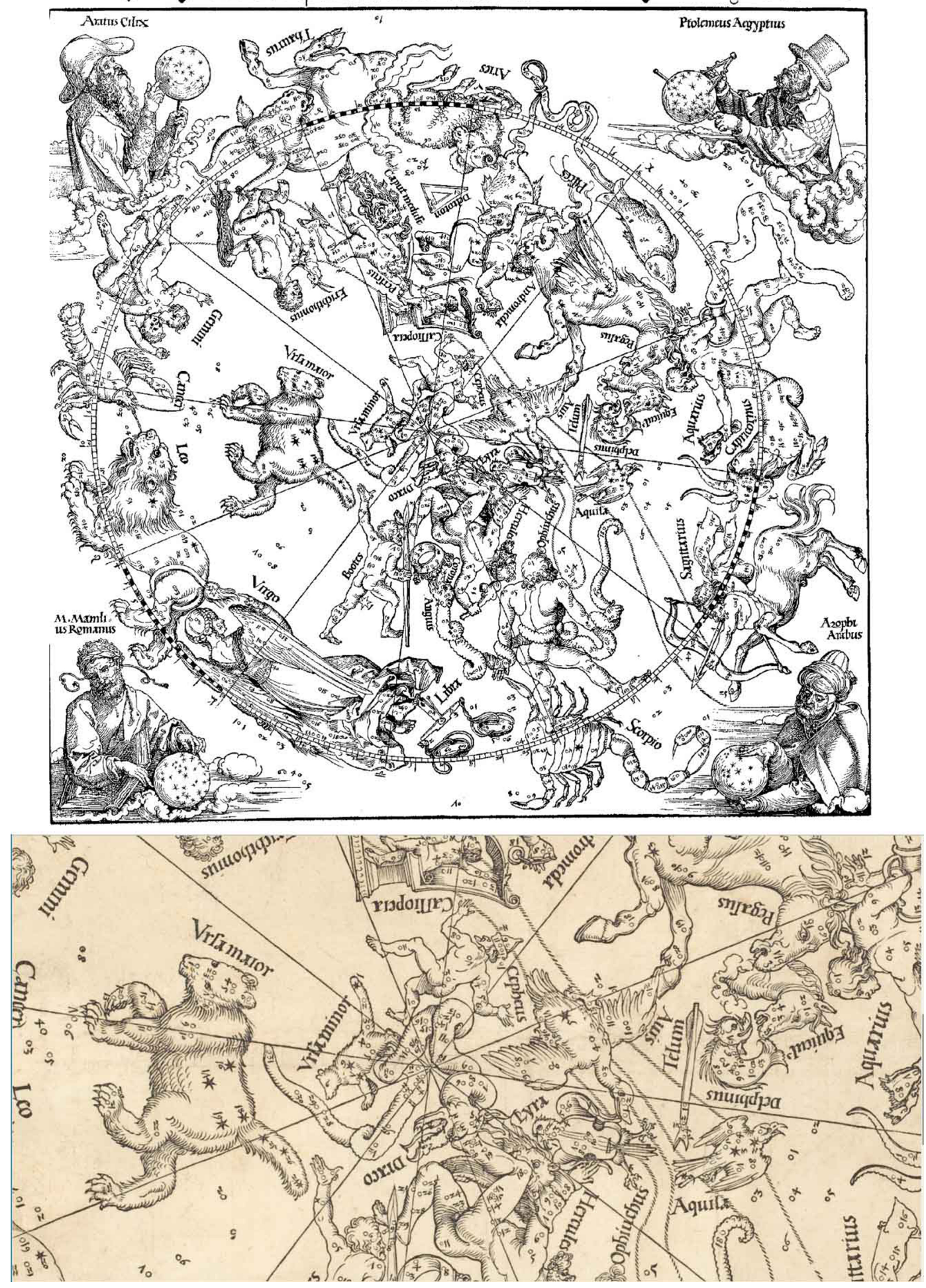

Figura 15: As constelações mais próximas do polo celeste norte são a do Dragão (Draco) e a Ursa Menor (Ursa Minor). Os navegantes utilizavam principalmente as estrelas da Ursa Menor (mais brilhantes) para localizar o polo norte. A constelação

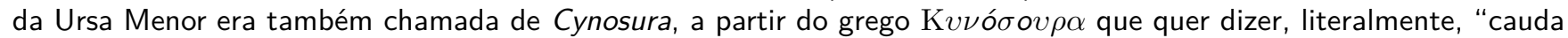
do cachorro". A estrela $\alpha$ da Ursa Menor era considerada, no período medieval, como a estrela dos navegantes, embora estivesse a alguns graus de distância do polo norte. (Fonte da imagem: Wikipedia. Xilogravura de Albrecht Dürer, 1515, mostrando as constelações celestes do hemisfério norte) 


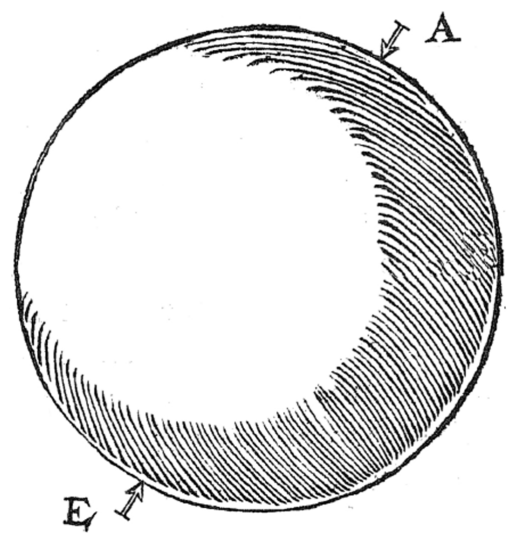

Figura 16: Para a realização do experimento descrito neste capítulo, a pedra magnética deve ser torneada para ficar esférica; e deve ser presa por pinos, em seus polos, de tal modo que possa girar facilmente em torno deles. A pedra deve ser homogênea e seu centro de gravidade deve estar exatamente na reta que une os dois polos. Imagem adaptada a partir de uma gravura de William Gilbert [91].

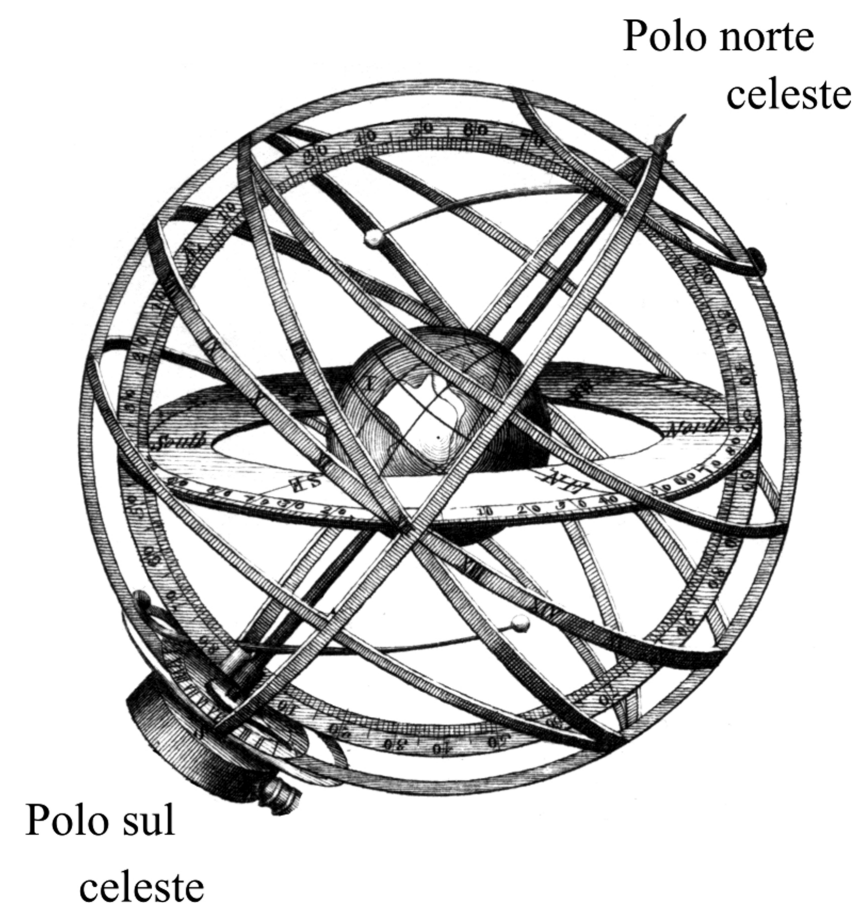

Figura 17: Uma esfera armilar representa a Terra no centro do universo e indica alguns dos círculos celestes. Nesta figura, o anel horizontal representa o plano do horizonte referente à posição onde o observador está situado, com a indicação das direções norte e sul. A ponta da esfera armilar indica a direção do polo norte celeste, inclinada em relação ao horizonte. A posição da esfera magnética, no experimento descrito por Petrus Peregrinus neste capítulo, deveria ser exatamente como a posição da Terra nesta ilustração, com o eixo no plano do meridiano. (Fonte da imagem: Wikipedia; plate LXXVII, Encyclopaedia Britannica, 1771)

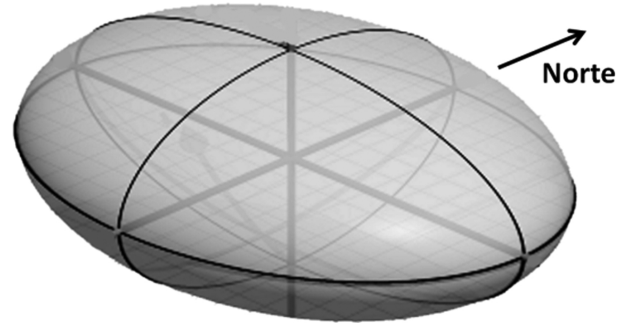

Figura 18: A pedra magnética deve ser limada até ficar com uma forma semelhante a um elipsoide, sendo o eixo de simetria do elipsoide perpendicular à reta que passa pelos seus polos magnéticos. (Fonte da imagem: Ellipsoid, Encyclopedia of Mathematics, disponível em https: //www encyclopediaofmath.org/index.php/Ellipsoid)

dispensado qualquer relógid 63 pois por ele você poderá saber a ascensão a qualquer hora que quiser, e também todas as outras disposições do céu que são buscadas pelos astrólogos 64

\section{PARTE II}

\section{Capítulo 1. Sobre a composição de um instrumento pelo qual pode ser conhecido o azimute do Sol, da Lua e de qualquer estrela no horizonte}

Tendo visto os efeitos naturais do magneto, abordamos a apresentação de inventos que dependem do conhecimento das suas próprias operações naturai:65. Deve ser tomado um magneto redondo, encontrando os polos, como foi dito; e seja limado entre os dois polos, em dois lados, para que a pedra fique como uma esfera comprimida entre os polos, para ocupar um espaço menor.

Então essa pedra, assim preparada, deve ser presa entre dois pratos, como um espelha 6 e os pratos

${ }^{63} \mathrm{O}$ próprio magneto funcionaria como um relógio, já que realizaria uma rotação a cada 24 horas.

${ }^{64}$ Nessa época, geralmente o termo "astrólogo" tinha o mesmo significado que "astrônomo"; porém, neste caso específico, o autor parece estar se referindo à astrologia propriamente dita. ${ }^{65}$ Ao contrário do que muitos afirmam, Petrus Peregrinus não propôs no seu artigo a construção de bússolas, ou seja, instrumentos destinados a conhecer a direção norte-sul através de efeitos magnéticos. Nesta segunda parte de seu tratado, ele indica a construção de instrumentos mais complexos do que uma bússola, cujo objetivo é determinar o azimute do Sol, da Lua ou de uma estrela. Isso fica claro pelo próprio título deste capítulo.

${ }^{66}$ Petrus Peregrinus está se referindo, neste ponto, a um estojo protetor de espelhos portáteis. No período medieval eram utilizados espelhos de metal polido, cristal de rocha e vidro. Eles eram geralmente redondos, pequenos e muito valiosos [93]. Muitas vezes eram protegidos por envoltórios redondos, 

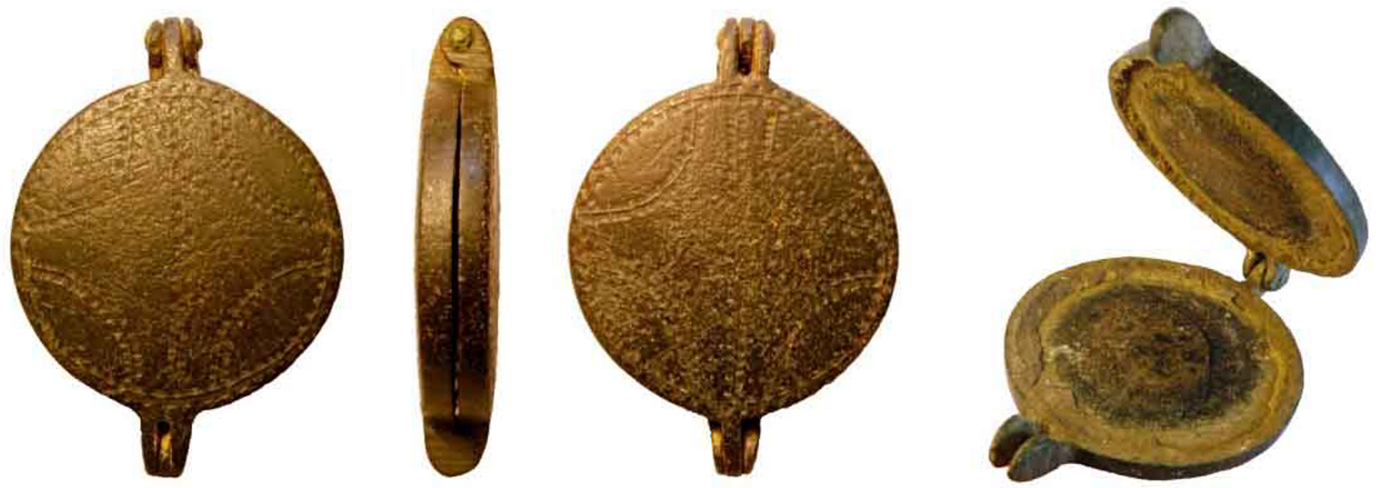

Figura 19: Um exemplo de estojo medieval para espelho. Este estojo, do século XIII ou XIV, tem diâmetro de 3,1 cm e foi encontrado em Norfolk, Inglaterra. (Fonte das imagens: disponível em https://finds.org.uk/database/artefacts/ record/id/446386)

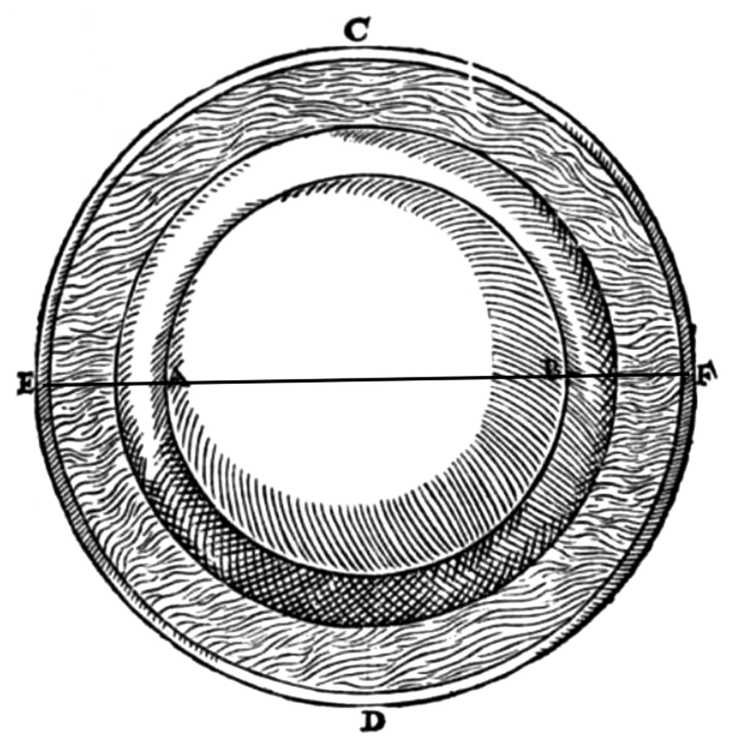

Figura 20: No dispositivo descrito por Petrus Peregrinus, a pedra magnética achatada $A B$ fica presa entre dois pratos de madeira e flutua em um recipiente ECFD cheio de água. Nas bordas do recipiente externo são marcados os pontos $\mathrm{E}$ e $\mathrm{F}$ que indicam as direções norte e sul, respectivamente. Eles são unidos por um fio, que passa acima do estojo de madeira que contém a pedra magnética. Essa linha indica a direção do meridiano. Imagem adaptada a partir de gravura da obra de William Gilbert [94].

devem ser unidos entre si, de modo que depois não se abram, para que a água não possa entrar. Os pratos devem ser preparados com cola adequada e os pratos devem ser de madeira leve67.

como os espelhos de bolsa utilizados hoje em dia (ver Fig. 19).

${ }^{67}$ Desse modo, a pedra magnética que havia sido limada, para ficar mais fina e leve, ficaria presa no meio de uma espécie de estojo de madeira, hermeticamente fechado, capaz de flutuar na água.

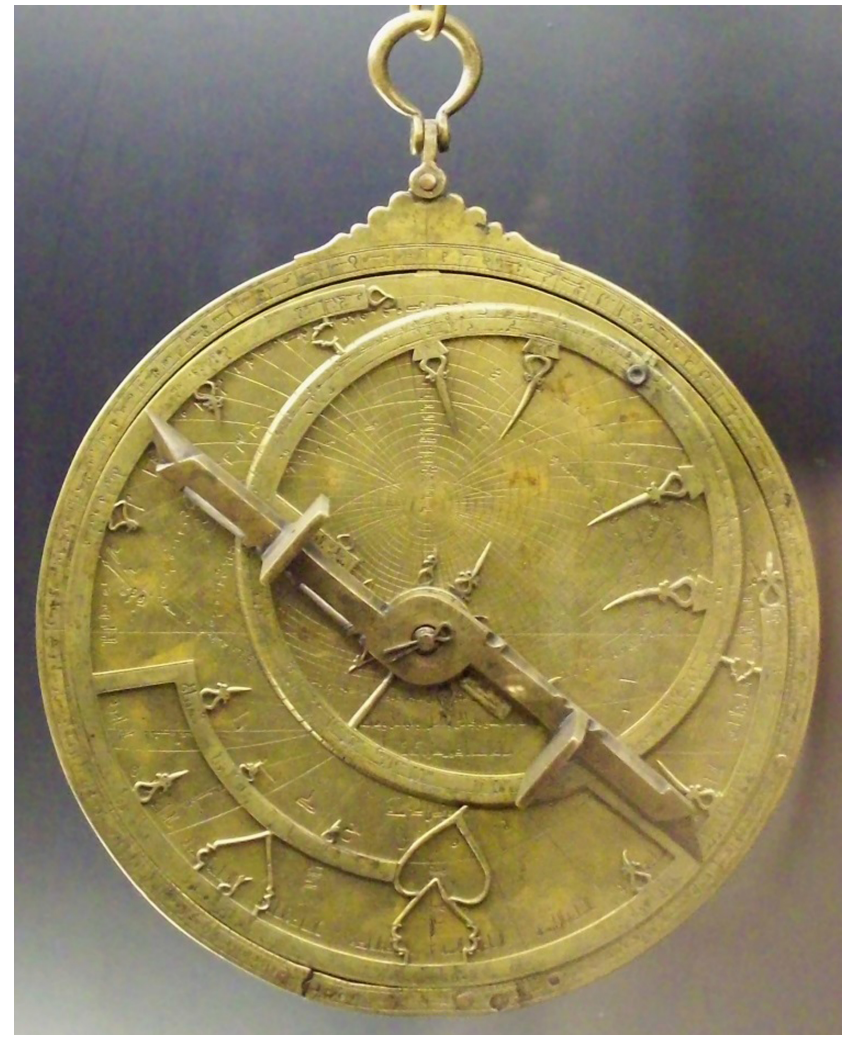

Figura 21: Astrolábio islâmico construído em 1067 d.C., chamado "Astrolabio de al-Sahlî", Museu Arqueológico de Madrid. Petrus Peregrinus indica que o prato de madeira superior deve ser marcado como um astrolábio desse tipo. A régua capaz de girar, presa ao centro do astrolábio, era chamada "alidada". (Fonte da imagem: fotografia de Luis García, disponível na Wikipedia)

Isso feito, coloque os pratos assim preparados em um grande recipiente cheio de água, no qual as duas direções do mundo, ou seja, sul e norte, foram descobertas e marcadas; e sejam indicadas por um 


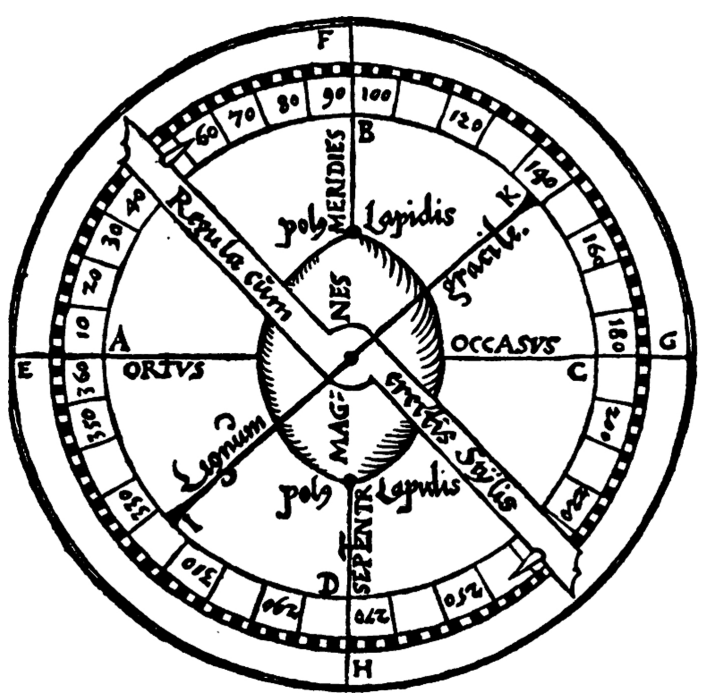

Figura 22: Ilustração do instrumento descrito no primeiro capítulo da segunda parte, publicado no século XVI. A figura mostra a pedra magnética (magnes) e seus polos (embora ela não fosse visível, pois era encerrada entre dois pratos de madeira); mostra a vareta de madeira (lignum gracile) que, na verdade, era utilizada e depois descartada, não permanecendo no aparelho final; indica corretamente a divisão do prato de madeira superior em quatro partes, com as indicações dos pontos principais: $\mathrm{F}=$ sul (meridies), G = oeste (occasus), $\mathrm{H}=$ norte (sepentr.), $\mathrm{E}=$ leste (ortus) e a divisão de cada quadrante em 90 partes ou graus. A régua presa ao centro do aparelho (regula cum erectis stilis) tem duas pontas que seriam perpendiculares à superfície do prato de madeira [95].

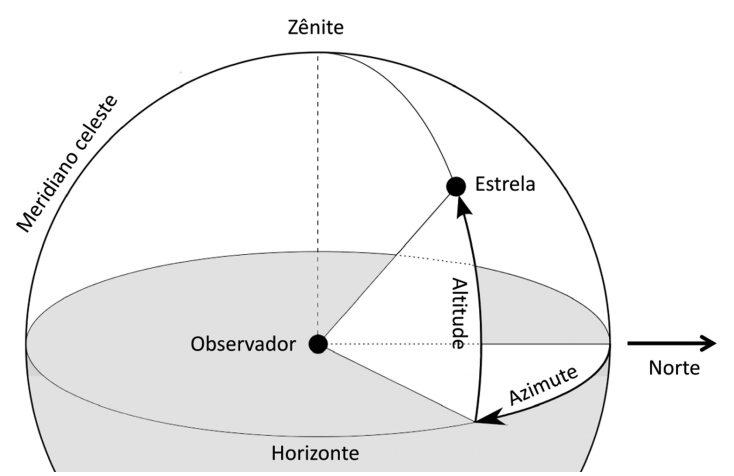

Figura 23: Este esquema explica o significado do azimute do Sol (ou de outro astro). É o ângulo entre o plano do meridiano e o plano vertical que passa pelo observador e pelo astro. (Fonte da imagem: Wikipedia, com colocação dos termos em português)

fio estendido desde o lado norte do vaso até o lado sul.

Deixe os pratos flutuarem então, e sobre eles coloque-se uma madeira fina, como um diâmetrq 68 .

\footnotetext{
${ }^{68} \mathrm{~A}$ vareta de madeira deve ser colocada diametralmente sobre o prato de madeira superior.
}

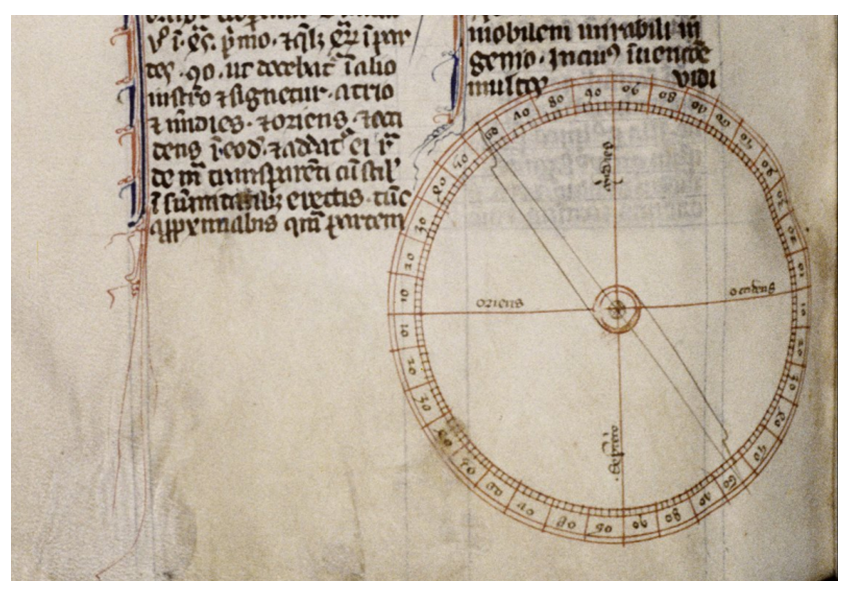

Figura 24: Ilustração de um manuscrito do tratado de Petrus Peregrinus, mostrando o instrumento descrito no primeiro capítulo da segunda parte. O desenho mostra apenas aquilo que deve ser colocado sobre o prato superior de madeira. Oxford, Bodleian Library, MS Ashmole 1522 (século XIV), fol. 186r. (Fonte da imagem: http://bodley30. bodley.ox.ac.uk:8180/luna/servlet/s/vqq159)

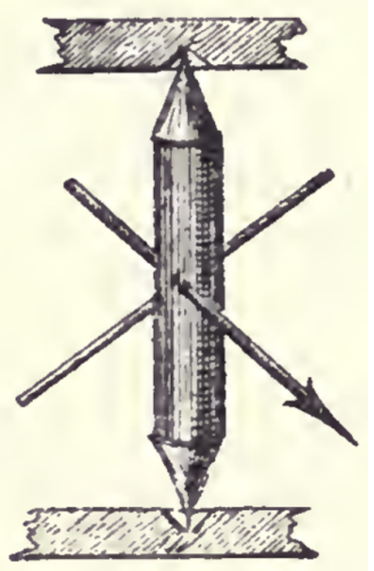

Figura 25: Diagrama explicativo do eixo vertical, no instrumento descrito por Petrus Peregrinus no segunda capítulo da segunda parte de seu tratado [96].

Mova [gire] então essa madeira sobre os pratos, até que fique paralela ou igual à linha do meridiano, anteriormente marcada pelo fio. Isso feito, trace sobre os pratos uma linha com a direção da madeira; ela será sempre a linha do meridiano, em todos os lugares 69 Essa linha deve depois ser dividida ao meio perpendicularmente, e essa será a linha do oriente e do ocidente [leste-oeste]. E assim você terá quatro quartos marcados realmente sobre os pratos, que in-

\footnotetext{
${ }^{69} \mathrm{Ou}$ seja: marcou-se agora sobre o prato de madeira superior uma linha, na direção norte-sul. Sempre que o dispositivo estiver flutuando sobre a água, ele adquirirá a mesma direção e indicará, portanto, o meridiano.
} 


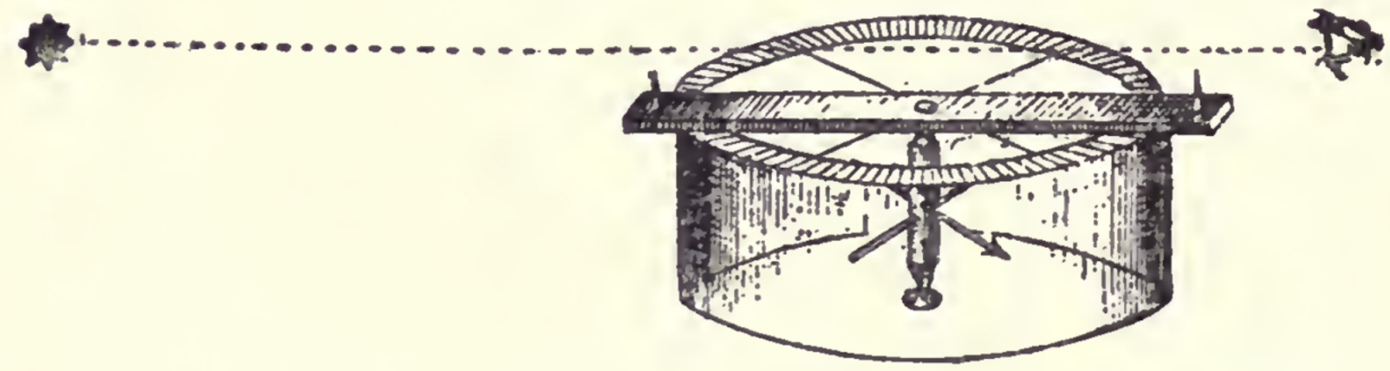

Figura 26: Diagrama explicativo do uso do segundo instrumento descrito por Petrus Peregrinus. Como foi explicado, o recipiente onde o aparelho é montado não precisa ser redondo, exteriormente; é a sua parte interna que é torneada e redonda [96].

dicam as quatro direções do mundo; cada uma delas deve ser dividida em noventa partes, para que haja na circunferência completa dos pratos 360 partes ao todo; e inscreva nela as partes, como se costuma escrever no dorso de um astrolábio. Além disso, sobre os pratos assim marcados deve-se colocar uma régua fina e leve, como a régua no dorso do astrolábio. Mas no lugar dos pinos, devem-se colocar duas pontas verticais nas extremidades da régua.

Então, se você quiser obter o azimute do Sol, de dia, coloque os pratos na água e deixe que eles se movam até pararem na sua posição. Segure-os firmemente com uma mão e com a outra gire a régua até que a sombra do pino caia na direção do seu comprimento. Então a extremidade da régua, do lado do Sol, indicará o azimute do Sol. Se houver vento, os pratos devem ser cobertos com algum recipiente, até adquirirem sua posição.

De noite, você fará o mesmo com a Lua e as estrelas, pela vista [e não pela sombra]; gire a régua, até que as extremidades dos pinos e a Lua ou estrela estejam sobre a mesma linha; a extremidade da régua do lado da estrela mostrará seu azimute, como anteriormente 70

Pelo azimute você conhecerá de forma completa as horas, os ascendentes e ascensões e tudo o que interessa, de acordo com a teoria do astrolábid ${ }^{71}$ Este desenho do instrumento mostra a doutrina apresentada $\sqrt{72}$

\footnotetext{
${ }^{70}$ Somente seria possível determinar o azimute da Lua ou de alguma estrela pelo método descrito por Petrus Peregrinus se o astro estiver perto do horizonte.

${ }^{71}$ Petrus Peregrinus escreveu também um tratado sobre o astrolábio, do qual foram conservados alguns poucos manuscritos.

${ }^{72}$ Os manuscritos do tratado de Petrus Peregrinus geralmente apresentam três figuras, correspondentes aos três aparelhos descritos na segunda parte da obra.
}

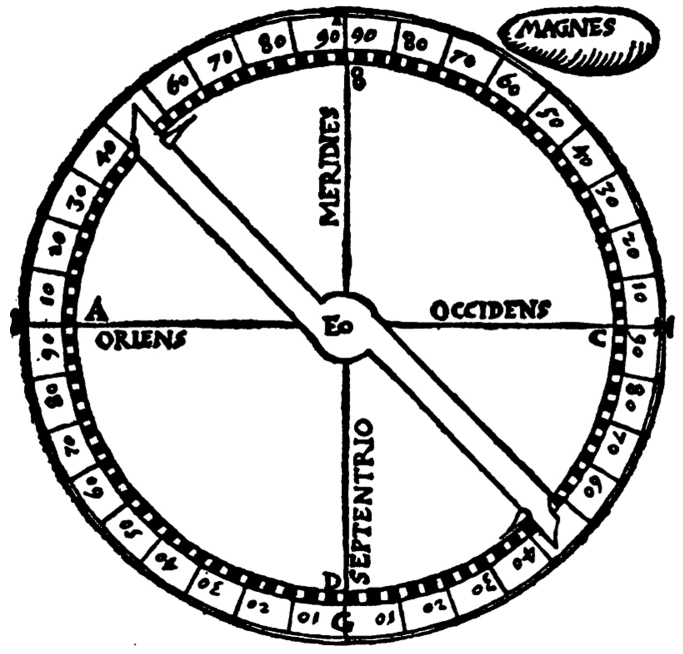

Figura 27: Ilustração do instrumento descrito no segundo capítulo da segunda parte, publicado no século XVI. A figura não mostra a parte interna do dispositivo, apresentado apenas aquilo que está na sua parte superior. Representa o momento no qual se aproxima uma pedra magnética (magnes) do aparelho, para magnetizar a agulha de aço que está dentro dele [98].

\section{Capítulo 2. Sobre a composição de um instrumento melhor, para a mesma função}

Neste capítulo nós lhe apresentaremos o modo de composição de um outro instrumento melhor, que produz efeitos mais corretos 73 . Deve-se fazer um recipiente de madeira, ou de bronze, ou de algum outro material sólido, torneando-o como uma caixa pouco profunda e bastante ampla ${ }^{74}$. Prenda sobre ela uma cobertura de material transparente, como

\footnotetext{
${ }^{73}$ Trata-se de outro instrumento para obter o azimute do Sol e de outros astros, e não de uma bússola, como se costuma afirmar.

${ }^{74} \mathrm{O}$ instrumento não é redondo por fora e sim possui uma cavidade redonda, produzida no torno.
} 
vidro ou cristal. Se todo o recipiente for de matéria transparente, será melhor. Deve-se então dispor no meio desse recipiente um eixo fino de bronze ou de prata, prendendo suas extremidades dos dois lados à caixa, acima e abaixd ${ }^{75}$. Devem existir dois furos, perpendiculares entre si, no meio do eixo; e um pedaço fino de ferro, como uma agulha, deve passar por um dele 76 e um outro pedaço fio de prata ou de bronze deve atravessar o outro furo, perpendicularmente ao ferro.

A cobertura deve ser primeiro dividida em quatro, e cada um desses quartos em noventa partes, como foi ensinado no outro instrumento; e lá devem ser marcados o norte e o sul, leste e oeste; e deve ser adicionada uma régua de material transparente,

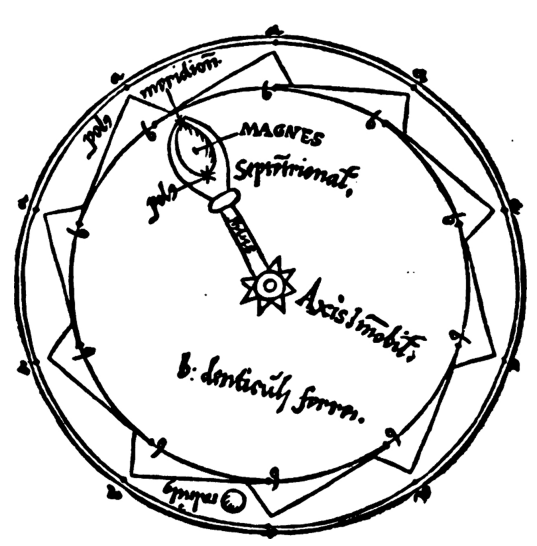

Figura 28: Ilustração do moto perpétuo descrito no terceiro capítulo da segunda parte, publicado no século XVI. A figura mostra a parte interna do dispositivo. Não se consegue compreender o funcionamento do aparelho, por esta imagem. A figura mostra tanto dentes quanto pinos de ferro (estes são indicados pelas pequenas letras "b"). A pedra magnética (magnes) está colocada em posição radial, ao contrário da descrição do texto, e assim seu polo inferior não produziria nenhum efeito significativo. A pequena esfera está na parte inferior e, aparentemente, ficaria sempre presa entre o mesmo par de dentes, não auxiliando de modo nenhum o movimento da roda. Ao contrário da descrição do texto, os dentes não são curvos a [102]

${ }^{a} \mathrm{O}$ mais antigo autor que encontramos que critica o desenho deste dispositivo foi Francesco Terzi de Lana, que transcreveu sua descrição e comentou que não iria reproduzir a figura porque não estava de acordo com o texto [103].

\footnotetext{
${ }^{75} \mathrm{Ou}$ seja: o eixo é vertical, preso no meio da caixa, sendo fixado por uma ponta no centro da cavidade e pela outra ponta no centro da cobertura transparente (ver Fig. 25).

${ }^{76} \mathrm{No}$ instrumento descrito no capítulo anterior era utilizada uma pedra magnética natural. Neste, é usada uma agulha de aço, que será magnetizada posteriormente.
}

com pontas eretas nas extremidades 77 . Então você aproximará ao cristal uma parte do magneto que desejar, seja norte ou sul, até que a agulha se mova para esse magneto e receba dele seu poder ${ }^{78}$. Isso feito, gire a caixa até que uma ponta da agulha pare na direção norte do instrumento, na direção do norte celeste79. Tendo realizado isso, gire a régua para o Sol, de dia, ou para as estrelas, de noite, do modo descrito acima.

Através deste instrumento você dirigirá seus passos para as cidades e ilhas e para qualquer lugar do mundo; e onde você estiver, sobre a terra ou sobre o mar, desde que lhe sejam conhecidas suas longitudes e latitudes.

Narraremos no livro "Sobre as operações dos espelhos $\sqrt{80}$ como o ferro fica parado no ar pelo poder da pedra ${ }^{81}$ E esta é a descrição do instrumento mencionado.

\section{Capítulo 3. Sobre a composição da roda}

Neste capítulo eu lhe revelo o modo de construir uma roda que gira continuamente, por um invento maravilhos 82 Já vi muitos se enganarem e se can-

\footnotetext{
${ }^{77} \mathrm{Ou}$ seja: a parte superior deste segundo instrumento é praticamente idêntica à do primeiro instrumento; a diferença principal é que tanto a cobertura do instrumento quanto a régua são transparentes.

${ }^{78}$ Não há nenhuma vantagem em magnetizar a agulha de aço depois de montar toda a aparelhagem; seria mais conveniente magnetizá-la desde o início.

${ }^{79}$ Uma ponta da agulha magnetizada apontará para a direção norte, independentemente da posição da caixa; o que Petrus Peregrinus está querendo dizer é que a caixa deve ser girada até que a marcação da direção norte que foi feita na sua cobertura coincida com a direção apontada pela agulha.

${ }^{80}$ Não são conhecidos manuscritos desta obra. No entanto, há uma referência elogiosa de Roger Bacon aos estudos de Petrus Peregrinus sobre óptica.

${ }^{81}$ Desde a Antiguidade havia relatos sobre estátuas de ferro que ficavam suspensas no ar, pela ação de magnetos. No entanto, isso é impossível; embora um conjunto de magnetos colocados acima de um objeto de ferro possa contrabalançar o seu peso, o equilíbrio será instável, ou seja, qualquer pequena mudança de posição do objeto fará com que ele caia ou suba. No século XVI, Giambattista della Porta discutiu esse suposto fenômeno: "Cansei-me muito tempo tentando fazer um ferro ficar suspenso no ar, sem encostar no magneto e sem estar preso por baixo; e atualmente julgo que isso é uma coisa impossível. [...] Petrus Pellegrinus [sic] diz que ele mostrou um modo de fazê-lo, em uma outra obra; mas não se conhece essa obra" [97]. O autor afirma que é possível simular o efeito colocando magnetos acima do objeto de ferro e prendendo-o por baixo com um fio invisível.

${ }^{82}$ Trata-se de um moto contínuo (perpetuum mobile), utilizando o magnetismo.
} 


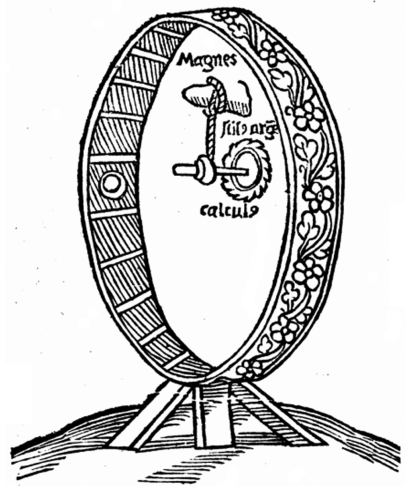

Figura 29: Ilustração de Jean Taisnier [104], publicada no século XVI, do moto perpétuo de Petrus Peregrinus. Na figura, foram indicados o magneto (magnes), a haste de prata (stil. arg.) e a pequena pedra redonda (calculo). A estrutura do aparelho não corresponde à descrição do texto, podendo-se perceber quão difícil era compreender aquilo que Petrus Peregrinus estava propondo.

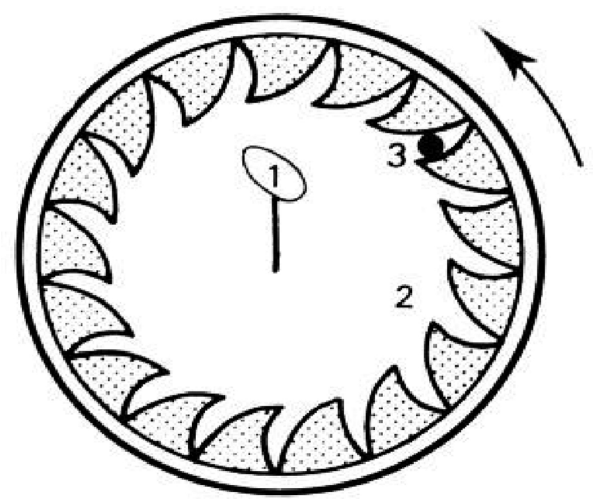

Figura 30: Representação do moto perpétuo de Petrus Peregrinus proposta por Patricia Radellet de Grave e David Speiser [105]. O número 1 indica a posição da pedra magnética que atrai os dentes de ferro; o número 3 indica a pequena esfera de prata ou de bronze. A seta indica o movimento da roda. Essa proposta de interpretação é totalmente inadequada, pois a atração dos dentes de ferro pelo magneto produziria uma rotação no sentido oposto ao indicado; e não se percebe como a pequena esfera pudesse auxiliar o movimento da roda.

sarem em múltiplos esforços para inventá-lo. Pois eles não perceberam que só se pode chegar a essa realização pelo poder ou potência dessa pedra 83 .

Para a composição ou construção dessa roda, tome um prato de prata, como um prato côncavo para

\footnotetext{
${ }^{83}$ Já existiam, antes de Petrus Peregrinus, tentativas de construção do moto perpétuo, mas sem utilizar magnetos. Algumas décadas antes dele, o arquiteto Villard de Honnecourt havia elaborado duas propostas de moto contínuo, provavelmente inspiradas por projetos islâmicos anteriores [99].
}

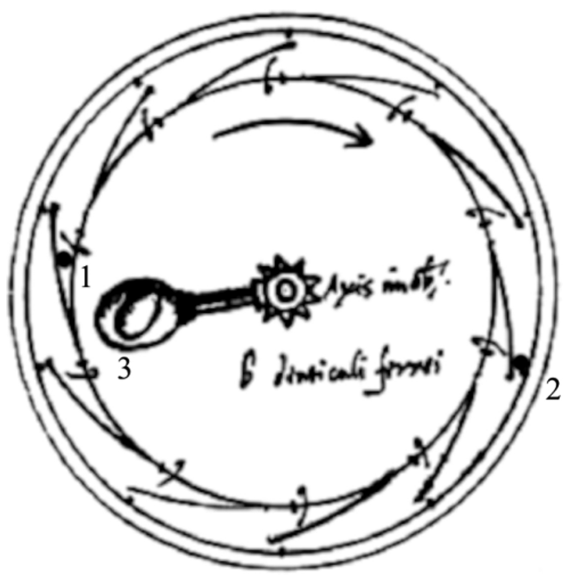

Figura 31: Esta é a mais recente de interpretação do moto perpétuo de Petrus Peregrinus, proposta por Andreas Kleinert, no estudo mais detalhado publicado até agora sobre o assunto [100,101]. A roda gira no sentido horário; o número 1 indica a pequena esfera de prata ou bronze, na posição em que ela sobe; e o número 2 indica a sua posição ao descer. Ela produz um torque maior ao descer, pois está mais distante do eixo de rotação, o que poderia ajudar o movimento da roda. O magneto está inclinado, em uma posição adequada para atrair os pequenos pinos de ferro.

espelhq ${ }^{84}$ trabalhado internamente com habilidade sutil, com perfurações e esculturas que você fara não apenas por causa da beleza, mas para aliviar o peso; pois quanto mais leve for, mais velozmente se moverá. Mas você o perfurá de modo que aquele que não puder ver dentro do prato não perceba o que foi lá inserido de modo suti ${ }^{85}$. No interior devem haver pequenos pinos ou pequenos dentes de ferro, com igual peso, fixados na borda, inclinados e aproximados de modo que um não fique mais distante do outro do que a espessura de uma fava ou grão de bico. Além disso, todas as partes dessa roda devem ter peso uniforme. Em seguida, fixe um eixo pelo centro, em torno do qual a roda deve girar, enquanto o eixo deve ficar totalmente imóvel; a esse eixo deve ser adicionada uma ponta de prata, colocada entre os dois pratos da caixa ${ }^{86}$ $\mathrm{Na}$ sua parte mais alta deve ser colocado o magneto, preparado deste modo: deve ser arredondado e seus polos encontrados, como foi dito; depois, deve lhe ser

\footnotetext{
${ }^{84}$ Não se trata de um espelho côncavo e sim do tipo de caixa para espelhos, já descrito anteriormente.

${ }^{85}$ Assim como no aparelho descrito no primeiro capítulo da segunda parte, está sendo utilizado um estojo para espelho, constituído por duas partes, de modo que aquilo que está dentro do dispositivo não possa ser observado.

${ }^{86}$ Essa ponta de prata, provavelmente vertical, não gira juntamente com a roda.
} 
dada uma forma oval, deixando os polos intactos, mas limando duas partes intermediárias opostas, para que ele fique comprimido, assim ocupando um espaço menor, sem tocar as bordas dos pratos durante o movimento da pequena roda. Tendo assim preparado o magneto, ele deve ser colocado sobre a ponta [de prata], como uma pedra em um anel, com o polo norte um pouco inclinado para os pequenos dentes da roda, para que seu poder influa sobre os pequenos dentes de ferro, não diametralmente, mas com alguma inclinação; para que cada pequeno dente chegue ao polo norte e o ultrapasse um pouco, pelo ímpeto da roda, chegando à parte sul; essa o repelirá em vez de atrair, como fica claro pela regra que anteriormente foi apresentada; e assim cada pequeno dente ficará sendo perpetuamente atraído e perpetuamente repelide 87 .

E para que a roda exerça sua função mais velozmente, prenda dentro dos pratos uma pequena peça redonda de bronze ou de prata, de tal tamanho que possa ser presa entre dois pequenos dentes; assim, quando a roda subir, a bolinha cairá na parte oposta. E como o movimento da roda é perpétuo, por um lado, então a queda da bolinha, no lado oposto, será perpétua, pois ela se encaixa entre dois pequenos dentes quaisquer. Pois, como ela tende para o centro da Terra pelo seu peso, proporcionará ajuda, para que os pequenos dentes não parem na direção da pedre8. Esses espaços entre os pequenos dentes devem ser encurvados de modo conveniente, para serem aptos a pegar a pequena esfera no lado de sua queda, como se mostra na figura aqui apresentada 89 .

Adeus.

Feito no campo, durante o cerco de Lucera, no ano do Senhor 1269, no dia 8 de agosto.

Fim deste tratado.

\footnotetext{
${ }^{87} \mathrm{~A}$ descrição não é totalmente clara, mas indica que o movimento da roda se daria através da atração e repulsão dos dentes de ferro (aço) pelos polos do magneto; esses dentes poderiam já estar magnetizados antes, ou ficariam magnetizados ao se aproximar do polo norte do magneto.

${ }^{88} \mathrm{O}$ dispositivo proposto por Petrus Peregrinus seria movido tanto pelo efeito magnético quanto por um efeito puramente mecânico, cuja descrição não é muito clara.

${ }^{89}$ Há várias figuras desse dispositivo (diferentes entre si) em diversos dos manuscritos do tratado de Petrus Peregrinus; no entanto, nenhuma delas parece ser uma representação adequada do aparelho descrito no texto [100, 101].
}

\section{Agradecimentos}

Este trabalho foi desenvolvido durante um estágio como pesquisador visitante do Instituto de Física de São Carlos (USP). O autor agradece o apoio recebido por parte da Fundação de Amparo à Pesquisa do Estado de São Paulo (FAPESP) e do Conselho Nacional de Desenvolvimento Científico e Tecnológico $(\mathrm{CNPq})$, que possibilitou a realização desta pesquisa.

\section{Referências}

[1] N. Weill-Parot, Philosophical Readings 7, 55 (2015).

[2] N. Weill-Parot, op. cit., p. 56.

[3] L. Delatte, Textes Latins et Vieux Français Relatifs aux Cyranides (E. Droz, Paris, 1942), p. 263.

[4] N. Weill-Parot, op. cit.

[5] J.A. Smith, Journal of Medieval History 18, 24 (1992).

[6] J.A. Smith, op. cit., p. 32.

[7] J.A. Smith, op. cit., p. 33.

[8] Petrus Peregrinus, The Letter of Petrus Peregrinus on the Gagnet, A.D. 1269 (McGraw Publishing Company, New York, 1904), p. 37.

[9] J.A. Smith, op. cit., p. 36.

[10] A.C. Mitchell, Terrestrial Magnetism and Atmospheric Electricity 37, 1205 (1932).

[11] J.A. Smith, op. cit., p. 39.

[12] J.A. Smith, op. cit., p. 41.

[13] J.A. Smith, op. cit., p. 49.

[14] J. Klaproth, Lettre à M. le Baron de Humboldt sur l'Invention de la Boussole (Libraire Orientale Dondey-Dupré, Paris, 1834), p. 46-47.

[15] J. Klaproth, op. cit., p. 50-51.

[16] J.A. Smith, op. cit., p. 51.

[17] S.P. Thompson, Proceedings of the British Academy 2, 378 (1906).

[18] R. Bacon, The Opus Majus, edited by J.H. Bridges (Clarendon Press, Oxford, 1897), 2 vols.

[19] P. Duhem, in The Catholic Encyclopedia (Robert Appleton, New York, 1907-1912), 15 vols, vol. 12, p. 80.

[20] E. Grant, in Dictionary of Scientific Biography, edited by C.C. Gillispie (Scribners, New York, 1974), vol. 10, p. 532-540.

[21] C.M. d'Eril e G. Boffito, Trattato dell'Astrolabio di Pietro Peregrino di Maricourt (Istituto alla Querce, Firenze, 1906).

[22] V. Le Clerc, in Histoire Littéraire de la France (Firmin Didot; Treuttel et Wurtz, Paris, 1847), p. 96127.

[23] P.F. Purton, A History of the Late Medieval Siege, 1200-1500 (Boydell Press, Woodbridge, 2010), p. 71.

[24] É. Charles, Roger Bacon, Sa Vie, Ses Ouvrages, Ses Doctrines (L. Hachette, Paris, 1861), p. 17.

[25] S.P. Thompson, op. cit., p. 378. 
[26] J.A. Taylor, Muslims in Medieval Italy: The Colony at Lucera (Lexington Books, Lanham, 2005), p. 1-2.

[27] J.A. Taylor, op. cit., p. 11.

[28] M. Asua, in: Medieval Science, Technology, and Medicine: an Encyclopedia, edited by T.F. Glick, S. Livesey and F. Wallis (Routledge, New York, 2014), p. $177-178$.

[29] J.A. Taylor, op. cit., p. 143.

[30] S. Runciman, The Sicilian Vespers: A History of the Mediterranean World in the Later Thirteenth Century (Cambridge University Press, Cambridge, 2012), p. 124.

[31] É. Charles, op. cit., p. 15-16.

[32] R. Bacon, Opera Qucdam Hactenus Inedita. Vol. 1. Opus Tertium. Opus Minus. Compendium Philosophice, edited by J.S. Brewer (Longman, Green, Longman, and Roberts, London, 1859), p. 46-47.

[33] F. Picavet, Essais sur l'Histoire Générale et Comparée des Theologies et des Philosophies Médievales (Félix Alcan, Paris, 1913), p. 244-245.

[34] É. Charles, op. cit., p. 17.

[35] F. Picavet, op. cit., p. 249.

[36] F. Picavet, op. cit., p. 246.

[37] R. Bacon, op. cit., 1859, p. 43.

[38] P. Mandonnet, Revue Néo-Scolastique de Philosophie 20, 52 (1913).

[39] R. Bacon, op. cit., 1859, p. 383-384.

[40] A.C. Crombie, Science, Art and Nature in Medieval and Modern Thought (Hambledon Press, London, 1996), p. 57.

[41] A.C. Crombie, Robert Grosseteste and the Origins of Experimental Science, 1100-1700 (Clarendon Press, Oxford, 1971), p. 204.

[42] P. Mandonnet, op. cit., p. 66.

[43] H. Bate, Speculum Divinorum et Quorundam Naturalium, Parts XX-XXIII: On the Heavens, the Divine Movers, and the First Intellect. Edited by C. Steel and G. Guldentops (Leuven University Press, Leuven, 1996), p. 63-69.

[44] T. Bertelli, Bulletino di Bibliografia e di Storia delle Scienze Matematiche e Fisiche 1, 62 (1868).

[45] Petrus Peregrinus, Petri Peregrini Maricvrtensis de Magnete, Seu Rota Perpetui Motus, Libellus (Ulhart d. Ä., Augsburg, 1558).

[46] J. Taisnier, Opusculum Perpetua Memoria Dignissimum, de Natura Magnetis, et Eius Effectibus (Ioannem Birckmannum, Coloniae, 1562).

[47] W. Gilbert, De Magnete, Magneticisque Corporibus, et de Magno Magnete Tellure (Petrus Short, London, 1600).

[48] S.P. Thompson, op. cit., p. 408.

[49] T. Browne, Pseudodoxia Epidemica: Or, Enquiries Into Very Many Received Tenents, and Commonly Presumed Truths (Nath. Ekins, London, 1658), p. 50.

[50] A. Kircher, Magnes, Siue de Arte Magnetica; Opus Tripartitum Quo Vniuersa Magnetis Natura, Eiusque in Omnibus Scientijs \& Artibus Vsus, Noua Methodo Explicatur (Blasij Deuersin, \& Zanobij Masotti bibliopolarum, Roma, 1654), p. 18.

[51] W. Gilbert, op. cit., p. 5.

[52] W. Cave, Scriptorum Ecclesiasticorum Historia Literaria A Christo Nato Usque ad Saeculum XIV (Richard Chiswell, London, 1688), p. 742.

[53] N. Cabeo, Philosophia Magnetica (Franciscum Succium, Ferraria, 1629), p. 204.

[54] J.B. Ricioli, Almagestum Novum Astronomiam Veterem Novamque Complectens, in Tres Tomos Distributam (Haeredis Victorij Benatij, Bononiae, 1651), p. 329.

[55] G. Vitali, Lexicon Mathematicum Astronomicum Geometricum (Ludovic. Billaine, Paris, 1668), p. 501.

[56] T. Cavallo, A Treatise on Magnetism, in Theory and Practice: With Original Experiments (Printed for the author, London, 1795), the second edition, with a supplement, p. 37-62.

[57] T. Cavallo, op. cit., p. 40.

[58] T. Cavallo, op. cit., p. 62.

[59] D. Brewster, A Treatise on Magnetism, Forming the Article Under That Head in the Seventh Edition of the Encyclopcedia Britannica (Adam and Charles Black, Edinburgh, 1837), p. 6-7.

[60] W. Wenckebach, Natuur en Scheikundig Archief 5, 275 (1836).

[61] W. Wenckebach, Anali di Matematica Pura ed Applicata 7, 159 (1865).

[62] G.I.T. Libri, Histoire des Sciences Matheimatiques en Italie: Depuis la Renaissance des Lettres Jusqu'à̀ la fin du Dix-Septieme Sieİcle (J. Renouard et Cie., Paris, 1838-1841), vol. 2, p. 487-505.

[63] T. Bertelli, op. cit.

[64] G. Hellmann, Rara Magnetica, 1269-1599 (Asher, Berlin, 1898).

[65] C.S. Peirce, Prospectus of an Edition of the Treatise of Petrus Peregrinus on the Lodestone: Latin text, English Version, and Notes, with an Introductory History of Experimental Science in the Middle Ages ((s.n.), (s.l.), 1894).

[66] Petrus Peregrinus, Epistle of Petrus Peregrinus on the Magnet. Reproduced from a ms. written by an English hand about A.D. 1390 (Bernard Quaritch, London, 1900).

[67] Petrus Peregrinus, Epistle of Petrus Peregrinus of Maricourt (Chiswick Press, London, 1902).

[68] Petrus Peregrinus, The Letter of Petrus Peregrinus on the Magnet, A.D. 1269, (McGraw Publishing Company, New York, 1904).

[69] E. Grant, A Source Book in Medieval Science (Harvard University Press, Cambridge, 1974), p. 368-376.

[70] R.H. Allen, Star Names: Their Lore and Meaning (Dover, New York, 1963), p. 431.

[71] S.P. Thompson, Proceedings of the British Academy 6, 22 (1913). 
[72] J. Rosmorduc, Revue d'Histoire des Sciences 29, 59 (1976).

[73] J. Rosmorduc, op. cit., p. 57.

[74] W. Gilbert, op. cit., p. 18-24.

[75] W. Gilbert, op. cit., p. 84.

[76] W. Gilbert, op. cit., p. 157.

[77] W. Gilbert, op. cit., p. 127.

[78] J. Tainier, op. cit., p. 5.

[79] A. Kircher, Magnes, Sive de Magnetica Arte (Hermanni Seherus, Roma, 1641), p. 56.

[80] Petrus Peregrinus, Opera. Petrus Peregrinus de Maricourt, edited by L. Sturlese and R.B. Thomson (Scuola Normale Superiore, Pisa, 1995), p. 50.

[81] H.A. Azar, The Sage of Seville: Ibn Zuhr, His Time, and His Medical Legacy (American University in Cairo Press, Cairo, 2008), p. 77.

[82] Alfred of Sareshel, Alfred of Sareshel's commentary on the Metheora of Aristotle (E.J. Brill, Leiden, 1988), critical edition, introduction, and notes by James K. Otte, p. 39.

[83] J. Tainier, op. cit., p. 12.

[84] W. Gilbert, op. cit., p. 16.

[85] J. Tainier, op. cit., p. 7.

[86] G.I.T. Libri, op. cit., vol. 2, p. 66.

[87] P.J. Smith and J. Needham, Nature 214, 1213 (1967).

[88] G. Hellmann, Terrestrial Magnetism and Atmospheric Electricity 4, 72 (1899).

[89] A.C. Mitchell, Terrestrial Magnetism and Atmospheric Electricity 42, 241 (1937).

[90] Johannes de Sacrobosco, La Spheİre de Jean de Sacrobosco (Hierosme de Marnef et la Veufve Guillaume Cavellat, Paris, 1584), p. 25.

[91] W. Gilbert, op. cit., p. 72.

[92] W. Gilbert, op. cit., p. 223.

[93] C. Hourihane, The Grove Encyclopedia of Medieval Art and Architecture (Oxford University Press, Oxford, 2012), vol. 4, p. 310.

[94] W. Gilbert, op. cit., p. 222.

[95] Petrus Peregrinus, op. cit., 1558, fol D iv verso.

[96] Petrus Peregrinus, op. cit., 1904, p. 30.

[97] G. della Porta, Magiae Naturalis Libri XX (Horatium Saluianum, Neapoli, 1589), p. 139.

[98] Petrus Peregrinus, op. cit., 1558, fol E i verso.

[99] J. Wirth, Villard de Honnecourt, Architecte du XIIIe Siècle (Librairie Droz, Genève, 2015), p. 161-162.

[100] A. Kleinert, NTM International Journal of History \& Ethics of Natural Sciences, Technology \& Medicine 11, 155 (2003).

[101] A. Kleinert, in Comptes-Rendus du Séminaire Origine des Idées Scientifiques: Ruptures et Continuités (Centre Commun d'Histoire des Sciences et d'Epistémologie de Lille, Lille, 2005).

[102] Petrus Peregrinus, op. cit., 1558, fol E iii recto.

[103] F.T. Lana, Magisterium Naturce, et Artis. Opus Physico-Mathematicum (Jo. Maria Ricciardi, Brixia, 1684), p. 489.
[104] J. Taisnier, op. cit., p. 15.

[105] P.R. de Grave and D. Speiser, Revue d'Histoire des Sciences 28, 230 (1975). 